Universidade de São Paulo

Escola Superior de Agricultura "Luiz de Queiroz"

Amarelo da ameixeira: modelo de colonização do hospedeiro por um

fitoplasma associado à doença

Sarah Rodrigues Galvão

Dissertação para obtenção do título de Mestra em Ciências. Área de concentração: Fitopatologia

\title{
Piracicaba
}

2015 
Sarah Rodrigues Galvão

Engenheira Agronôma

\section{Amarelo da ameixeira: modelo de colonização do hospedeiro por um} fitoplasma associado à doença

Orientador:

Prof. Dr. IVAN PAULO BEDENDO

Dissertação apresentada para obtenção do título de Mestra em Ciências. Área de concentração: Fitopatologia 


\title{
Dados Internacionais de Catalogação na Publicação DIVISÃO DE BIBLIOTECA - DIBD/ESALQ/USP
}

\author{
Galvão, Sarah Rodrigues \\ Amarelo da ameixeira: modelo de colonização do hospedeiro por um fitoplasma \\ associado à doença / Sarah Rodrigues Galvão - - Piracicaba, 2015. \\ 52 p. : il. \\ Dissertação (Mestrado) - - Escola Superior de Agricultura "Luiz de Queiroz".
}

1. Fitoplasma 2. Ameixeira 3. Colonização 4. Flutuação sazonal 5. Mollicutes I. Título

\section{CDD 634.22}

G182a

"Permitida a cópia total ou parcial deste documento, desde que citada a fonte - 0 autor" 
Aos meus pais, Renilda e João Carlos, pelo amor incondicional Ao Leonardo, pelo incentivo e companheirismo DEDICO.

"Quem não anda não cai, mas também permanece sempre no mesmo lugar". Padre Fábio de Melo

Aos meus irmãos, Brenda e Gabriel Pela amizade e carinho, OFEREÇO. 


\section{AGRADECIMENTOS}

Agradeço primeiramente a Deus e a Santa Rita de Cássia, que sempre me iluminam e guiam os meus passos.

Aos meus pais, Renilda e João Carlos e aos meus irmãos, Brenda e Gabriel por sempre estarem ao meu lado, por todo amor e apoio incondicional nessa etapa da minha vida.

Ao meu noivo Leonardo, pela paciência, amor e cuidados de sempre.

À Escola Superior de Agricultura "Luiz de Queiroz" e ao Departamento de Fitopatologia pela oportunidade e conhecimentos concedidos.

Ao Conselho Nacional de Desenvolvimento Científico e Tecnológico, CNPq pela concessão da bolsa de mestrado.

Ao Professor Ivan Paulo Bedendo, gostaria de agradecer a confiança, amizade, oportunidade oferecida e aos ensinamentos que contribuíram e muito para a minha formação profissional e pessoal.

Ao Professor Luis Eduardo Aranha Camargo, pelos conselhos, orientações e pela contribuição na utilização dos recursos do seu laboratório.

À Dra Daniela Flôres, pela coleta das amostras e pelos ensinamentos os quais foram fundamentais para realização desse trabalho.

Aos amigos do Laboratório de Genética Molecular, Fernanda Moretti, Mariana Cicarelli, Líllian Bibiano, Vanessa Macedo e em especial Raphael Severo, pela paciência, amizade e ajuda de sempre.

Aos colegas do Laboratório de Virologia Vegetal e ao funcionário Edivaldo Buriola, pelo bom convívio e amizade,

Aos amigos do Laboratório de Procariotos Fitopatogênicos, Ariane Carmo, Thays Benites, Ticyana Banzato e Jacson Ferreira, pela ajuda, ensinamentos, carinho e companheirismo.

Aos grandes amigos que conquistei nesses dois anos: Mariane, Pedro, Líllian, Thays, Ticyana, Renata, Viviana e Victor pelo apoio, amizade verdadeira, incentivo e pelos bons momentos vividos. Muito obrigada!

A todos os alunos, funcionários e professores do Setor de Fitopatologia da ESALQ/USP, que de alguma forma contribuíram para realização desse trabalho. 


\section{SUMÁRIO}

RESUMO

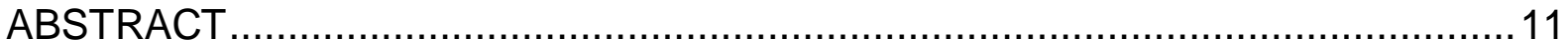

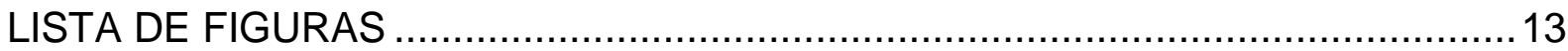

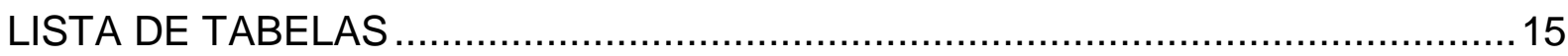

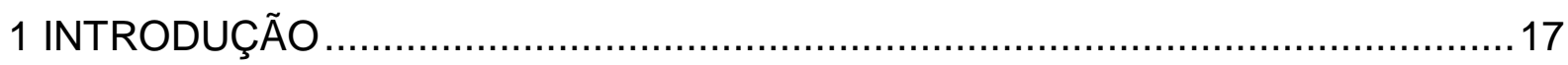

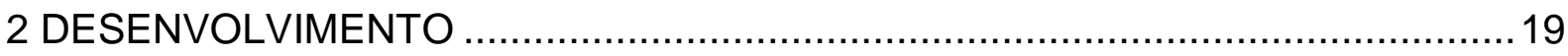

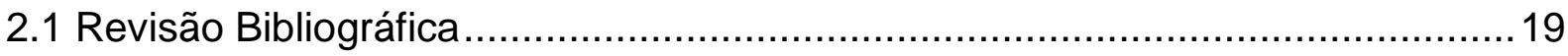

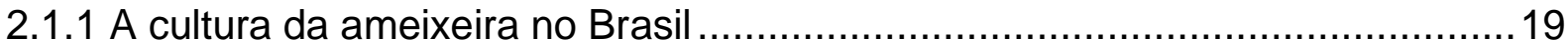

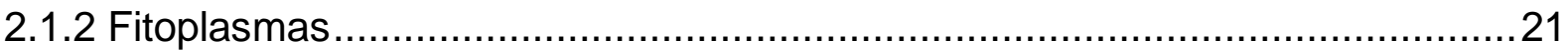

2.1.3 Um fitoplasma do grupo 16SrI encontrado em ameixeira e em outras espécies

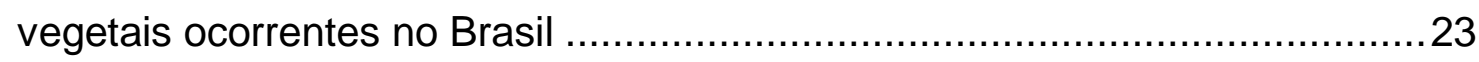

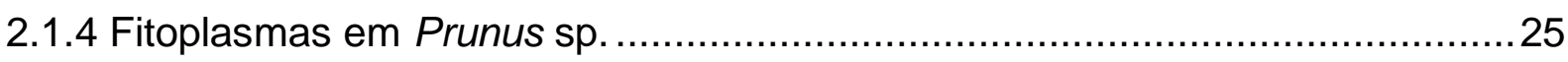

2.1.5 Colonização e flutuação sazonal dos fitoplasmas em plantas lenhosas ..........26

2.1.6 Reação em Cadeia da Polimerase em tempo real (qPCR) ............................28

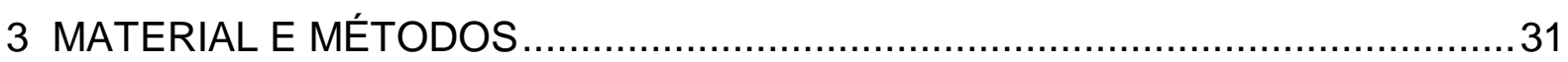

2.2.1 Montagem do ensaio e coleta das amostras ................................................

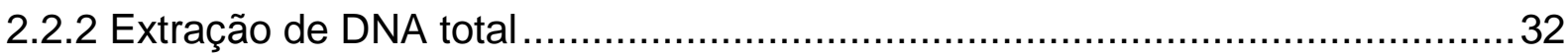

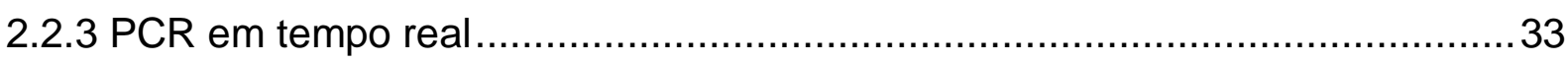

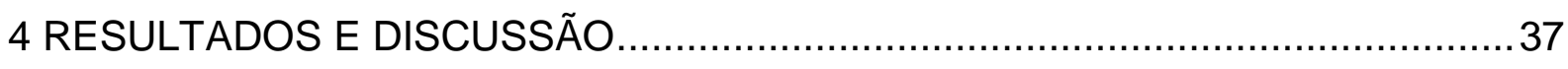

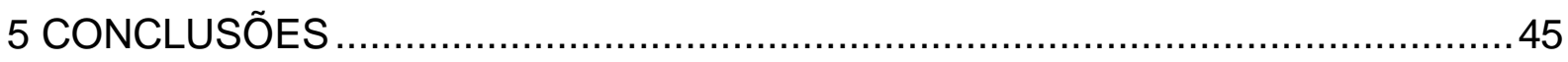

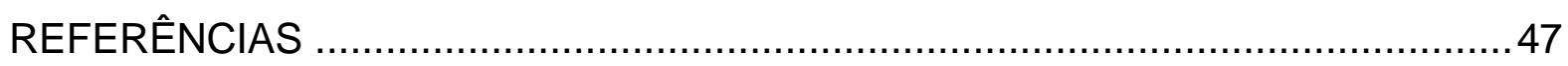




\section{RESUMO}

\section{Amarelo da ameixeira: modelo de colonização do hospedeiro por um fitoplasma associado à doença}

A cultura da ameixeira vem despertando a atenção de produtores brasileiros, pois oferece alta rentabilidade, possibilita a prática da agricultura familiar, emprega mão de obra, recebe incentivos de programas oficiais e conta com um mercado altamente promissor. No entanto, a cultura ainda necessita de cultivares com melhor adaptação climática, qualidade de frutos e resistência às doenças. Atualmente, dentre as doenças, o "amarelo das fruteiras de caroço", associada a um fitoplasma, vem causando sérios problemas. Em 2013, em pomares comercias de ameixeira (Prunus salicina), instalados em Paranapanema (SP), foram observadas plantas portadoras de sintomas tipicamente induzidos por fitoplasmas, caracterizados por superbrotamento de ramos, redução no comprimento de entrenós, além de amarelecimento, deformação e redução do tamanho de folhas. Nestas plantas foi identificado um fitoplasma pertencente ao grupo 16SrI-B (Candidatus Phytoplasma asteris). Visando aumentar os conhecimentos sobre este patossistema, o objetivo desse trabalho foi estudar a dinâmica da colonização de plantas comerciais de ameixa infectadas pelo fitoplasma. Para isso, em dois pomares, amostras da parte aérea e raiz de plantas sintomáticas, pertencentes às variedades Gulfblaze e Azteca, foram coletadas mensalmente, durante um ano. O DNA total foi extraído e submetido ao PCR em tempo real para quantificar o fitoplasma nos tecidos do hospedeiro. Nessas reações foram utilizados os iniciadores universais UniRNAForward/UniRNAReverse. O fitoplasma foi detectado em todas as amostras, tanto aquelas da parte aérea quanto de raízes, em ambas as variedades estudadas. A concentração do patógeno nos tecidos do hospedeiro variou de $5,3 \times 10^{3}$ a $4,54 \times$ $10^{6}$ e $3,28 \times 10^{3}$ a $1,28 \times 10^{6}$ número de cópias/100ng de DNA total, na parte aérea e nas raízes, respectivamente. Os resultados mostraram uma flutuação sazonal na concentração do fitoplasma, onde as maiores concentrações foram encontradas nas épocas mais quentes do ano, principalmente no mês de dezembro, e uma redução na concentração do patógeno foi observada nas épocas mais frias, embora o fitoplasma tenha permanecido na parte aérea da planta durante a fase de dormência do hospedeiro. A variedade Gulfblaze apresentou maior concentração do patógeno comparada com a variedade Azteca. O fitoplasma associado ao amarelo da ameixeira também foi encontrado em maior concentração na copa da planta. Com base nos resultados, amostras retiradas da parte aérea e nas épocas mais quentes do ano são as mais indicadas para os procedimentos de detecção do patógeno, visando uma diagnose mais confiável.

Palavras-chave: Fitoplasma; Ameixeira; Colonização; Flutuação sazonal; Mollicutes 


\section{ABSTRACT \\ Plum yellow: colonization model of the host by a phytoplasma associated with this disease}

Plum is a crop that has aroused the attention of Brazilian growers due to high profitability, family farming, incentive arrangement and promising market. However the plum culture still need of varieties with good climate adaptation, best quality fruit, and disease resistance. Currently, among the diseases, stone fruit yellows, associated with a phytoplasma have caused serious problems. In 2013, in commercial orchards of plum (Prunus salicina) located in Paranapanema (SP), plants were observed exhibiting symptoms typically induced by phytoplasmas, characterized by witches broom and shortened internodes. Besides, the leaves were yellowish, malformed, and reduced in size. In these plants was identified a phytoplasma belonging to the group 16SrI-B (Candidatus Phytoplasma asteris). The aim of the present work was to study the dynamics of colonization of commercial plants plum by the phytoplasma, in order to better understanding of the disease. Thus, in two orchards, samples from aerial parts and roots of symptomatic plants belonging to Gulfblaze and Azteca varieties were collected monthly, during a year. Total DNA was extracted and submitted to the Real Time PCR to quantify the phytoplasma in host tissues. In these reactions the universal primers UniRNAForward/UniRNAReverse were used. The phytoplasma was detected in all samples, both aerial parts and roots of the two varieties. The concentration of the pathogen in host tissues ranged from $5,3 \times 10^{3}$ to $4,54 \times 10^{6}$ and $3,28 \times 10^{3}$ to $1,28 \times$ $10^{6}$ number of copies/100 ng of total DNA in aerial parts and roots, respectively. The results showed a seasonal fluctuation in the concentration of phytoplasma. The highest concentrations were found in the warmer seasons of the year, especially in December, and a reduction in pathogen concentration was observed when the weather was milder, although the phytoplasma remained in aerial part of the plant during the dormant phase of the host. The Gulfblaze variety showed a higher concentration of the pathogen compared with the Azteca variety. In addition, the phytoplasma associated with the disease was found in highest concentration in the aerial part of plant. Based on the results, samples collected from the aerial part and in the warmer seasons of the year are the most recommended for pathogen detection procedures for safe diagnosis.

Keywords: Phytoplasma; Plum; Colonization; Seasonal fluctuation; Mollicutes 


\section{LISTA DE FIGURAS}

Figura 1 - Sintomas de fitoplasmas em plantas de ameixeira: A. Ramo com superbrotamento (à esquerda) e ramo assintomático (à direita), B. Sintomas de redução de tamanho foliar (à esquerda) e folhas normais (à direita), C. Sintomas de clorose e retorcimento de folhas, D. Sintoma de superbrotamento e redução no tamanho de folhas. (fotos gentilmente cedidas pela Dra Daniela Flôres). 24

Figura 2 - Localização dos pomares I e II em Paranapanema-SP. Fonte: FLÔRES, 2013.

Figura 3 - Representação esquemática de uma árvore de ameixeira, ilustrando a forma de coleta de amostras. A letra $\mathrm{C}$ corresponde à copa e $\mathrm{R}$ à raiz (R1 e R2: lados opostos do sistema radicular) Fonte: FLÔRES, 2013.

Figura 4 - Curva padrão de correlação entre concentrações conhecidas de DNA (número de cópias de fitoplasma) e valores de $\mathrm{Ct}$. (Y= $\mathrm{Ct}$ da amostra e $X=\log$ número de cópias de fitoplasma/100ng de DNA)

Figura 5 - Gel de agarose referente às reações amplificadas do qPCR. As amostras de 1 a 11 indicam plantas sintomáticas de ameixeira. As amostras $12 \mathrm{e}$ 13 são os controles positivo (fitoplasma do milho) e negativo (água), respectivamente. A seta vermelha indica $73 \mathrm{pb}, \mathrm{M}$ - marcador peso molecular (Low Molecular Weight DNA Ladder).

Figura 6 - Log do número de cópias de fitoplasma detectadas em 100 ng de DNA total de ameixeira (média total) via qPCR durante os 12 meses de avaliação, para copa e raiz. As barras representam o erro padrão da média. 


\section{LISTA DE TABELAS}

Tabela 1 - Localização e principais características dos pomares de ameixeira amostrados em Paranapanema SP. Fonte: FLÔRES,

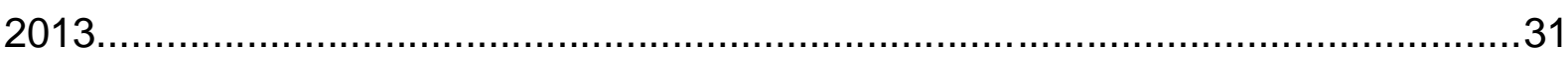

Tabela 2 - Concentração de fitoplasma (média total) em tecidos foliares e radiculares de ameixeira em distintas épocas do ano e diferentes ciclos vegetativos da planta. Concentração = número de cópias/100ng DNA total 39

Tabela 3 - Análise de variância dos efeitos da variedade (Var), parte da planta (copa ou raiz - $C / R$ ) e época de amostragem (EP) na concentração do patógeno. $e^{\text {ns }}=$ não significativo $(p>=.05)$; * significativo ao nível de $5 \%$ de probabilidade $(.01=<p<.05)$; * significativo ao nível de $1 \%$ de probabilidade $(p<.01)$

Tabela 4 - Influência da época de amostragem e parte da planta (copa ou raiz) na concentração do patógeno nos tecidos do hospedeiro. Concentração = número de cópias/100ng DNA total 


\section{INTRODUÇÃO}

A ameixeira é cultivada no Brasil há muitos anos, porém não se sabe ao certo quando foi introduzida no país. Duas espécies são predominantes entre as cultivares plantadas comercialmente. Uma delas, classificada como Prunus domestica (L.), é conhecida como ameixa europeia e, a outra, Prunus salicina Lindl, é plantada em maior escala e conhecida como ameixa japonesa. Atualmente, os maiores produtores são os estados do Rio Grande do Sul, com produção anual estimada em 12.200 toneladas; Santa Catarina, com 11.000 toneladas; Paraná, com 7.000 toneladas; São Paulo com 6.011 toneladas; e Minas Gerais com 1.600 toneladas. As principais cultivares plantadas são Gulfblaze, Azteca, Irati, Reubennel, Harry Pickstone. Em termos de produção, o Brasil não aparece nas estatísticas mundiais. A produção nacional de frutos não é suficiente para abastecer o mercado interno e, anualmente, são importadas cerca de 10.000 toneladas de ameixa de países vizinhos. O volume importado corresponde à metade da demanda nacional, evidenciando o enorme potencial de expansão que a cultura encontra no país.

A cultura da ameixeira no Brasil vem despertando a atenção de produtores, pois oferece alta rentabilidade, possibilita a prática da agricultura familiar, emprega mão de obra, recebe incentivos de programas oficiais e conta com um mercado altamente promissor. A cultura mostrou grande progresso em passado recente, porém este estímulo foi refreado devido à eliminação significativa de pomares na região Sul, provocada pelo ataque da bactéria Xylella fastidiosa, agente causal da escaldadura das folhas. Simultaneamente ao problema da escaldadura, a ocorrência da doença conhecida por "amarelo das fruteiras de caroço", a qual é associada a um fitoplasma, tem sido evidente em pomares comerciais. Assim, em 2013, em plantios instalados no vale do Paranapanema (SP), foram observadas plantas portadoras de sintomas tipicamente induzidos por fitoplasmas, caracterizados por superbrotamento de ramos, redução no comprimento de entrenós, além de amarelecimento, deformação e redução do tamanho de folhas, podendo ocorrer, inclusive, declínio da planta. Nestas plantas foi identificado um fitoplasma pertencente ao grupo 16Srl-B (Candidatus Phytoplasma asteris). Fitoplasmas são organismos procariotos, unicelulares, sem parede celular que habitam o floema e se distribuem de forma sistêmica pela planta. A doença está amplamente distribuída em diversas regiões do mundo e tem causado perdas econômicas significativas nas áreas de cultivo dos 
principais países produtores. Ressalta-se que o patógeno ataca outras espécies do gênero Prunus, tais como pessegueiro, damasqueiro e nespereira. É reconhecido que as fruteiras de clima temperado foram introduzidas em nosso país a partir de países do hemisfério norte. Uma vez que o patógeno é um habitante de floema e estas espécies são reproduzidas vegetativamente, é esperada sua ocorrência em pomares nacionais. Esta suspeita foi exatamente confirmada, pela primeira vez, nos referidos pomares implantados no Vale do Paranapanema (SP). No Brasil, são raros os estudos que exploram as doenças de fruteiras temperadas relacionadas aos fitoplasmas. A ameixeira está no foco da pesquisa deste trabalho, justamente por apresentar alto potencial econômico e pela doença associada aos fitoplasmas estar despertando a atenção dos produtores.

Algumas associações entre fitoplasmas e fruteiras de caroço têm sido estudadas em países de clima temperado. No entanto, investigações desta natureza seriam interessantes em regiões de clima tropical ou subtropical, nas quais as estações do ano não são bem definidas e, por consequência, a fisiologia da planta provavelmente seja distinta daquela encontrada em países de clima frio. Assim, o presente trabalho teve por objetivo o estudo da dinâmica da colonização de plantas comerciais de ameixa infectadas pelo fitoplasma associado ao amarelo em um pomar localizado no estado de São Paulo. Com a ampliação do conhecimento sobre a doença espera-se que os subsídios gerados possam contribuir para a determinação de um protocolo de diagnóstico rápido e seguro, bem como para a elaboração de um programa de manejo para minimizar os efeitos da doença. 


\section{DESENVOLVIMENTO}

\subsection{Revisão Bibliográfica}

\subsubsection{A cultura da ameixeira no Brasil}

A ameixeira pertence à família Rosaceae, subfamília Prunoideae e gênero Prunus (L.). Duas espécies principais são cultivadas, Prunus salicina (ameixeira japonesa) e Prunus domestica (ameixeira europeia). A ameixa japonesa é originária do Extremo Oriente e seus híbridos com espécies europeias e norte-americanas são as mais cultivadas no Brasil, onde encontraram condições climáticas favoráveis ao seu desenvolvimento, principalmente na região sul do país. Essas ameixeiras suportam o frio pouco intenso e toleram as temperaturas de verão (CASTRO et al., 1994). Já a ameixeira europeia, é originária das regiões do Cáucaso, da Turquia e da Pérsia (CASTRO et al., 2003). É muito importante no âmbito mundial, principalmente para comércio do produto na forma de passa. É pouco plantada no Brasil devido a sua exigência em número de horas de frio no inverno, com temperaturas iguais ou inferiores a $7,2^{\circ} \mathrm{C}$ (CASTRO et al., 1994). Dentre todas as frutíferas, a ameixeira foi a que mais se difundiu pelo mundo, sendo cultivada em várias condições climáticas, em virtude da diversidade de espécies e do resultado de hibridações ocorridas ao longo do desenvolvimento da cultura. Pode-se dizer que essa cultura está disseminada por todo o hemisfério norte, com exceção de zonas onde o elevado calor dos trópicos ou o extremo frio da zona polar são obstáculos ao seu desenvolvimento (CASTRO et al., 2003).

De acordo com os dados da FAO (FAOSTAT, 2015), mais de $50 \%$ da produção mundial concentra-se no continente asiático, cabendo a liderança à China, seguida dos Estados Unidos, Roménia, a antiga Jugoslávia e a Alemanha. A Europa tem uma representatividade na produção mundial da ordem de $34 \%$, destacando-se a Espanha como a maior produtora na União Europeia, com produções superiores, em média, a 500 mil toneladas anuais.

No Brasil, a ameixeira é cultivada desde o Rio Grande do Sul até Minas Gerais, porém, entre as fruteiras de clima temperado, essa cultura foi aquela que menos prosperou, devido à falta de cultivares com boa adaptação climática, à produção de frutos com baixa qualidade e aos problemas fitossanitários, com destaque para a escaldadura das folhas, doença causada pela bactéria Xylella 
fastidiosa, a qual foi responsável, na década de 70, pela erradicação de pomares no Rio Grande do Sul e Paraná (EIDAM et al., 2012). Entretanto, atualmente, o país apresenta uma demanda em torno de 50.000 toneladas anuais, sendo $30 \%$ desse total importado principalmente do Chile e da Argentina (MADAIL, 2003).

As variedades Gulfblaze e Azteca, ambas denominadas cultivares japonesas, são destaques entre as cultivares plantadas nos pomares brasileiros. A variedade Gulfblaze apresenta frutos que atingem de 100 a 120 gramas. Salienta-se a coloração externa vermelho-escura em toda a superfície do fruto, sendo a polpa amarelo-alaranjada. A cultivar apresenta baixa exigência de frio (400h), com floração e maturação precoces (CASTRO, 2008; MONTEIRO, 2004). Já a Azteca, de origem mexicana, se adaptou bem ao Brasil, sendo cultivada com sucesso no estado de São Paulo (FLÔRES, 2013). Ambas possuem o mesmo ciclo vegetativo: dormência (junho a julho); mobilização de reserva (agosto); brotação (setembro); floração (outubro); frutificação (novembro a janeiro); maturação dos frutos (final de janeiro a final de maio); e queda das folhas (final de maio). De setembro a março, a planta está em fase de crescimento, a fase de formação de reservas tem início em abril e a partir de junho a planta entra em dormência até a nova brotação em setembro (MONTEIRO et al., 2004). Os estádios fenológicos das fruteiras de caroço são as seguintes: gema dormente, gema inchada, botão rosado, botão aberto, plena floração, queda de pétalas, formação de frutos, crescimento dos frutos, maturação dos frutos, queda de folhas e dormência (MONTEIRO et al., 2004).

O cultivo da ameixa no Brasil apresenta boas perspectivas de investimento, pois o mercado mostra-se promissor. A planta possui alta rusticidade, boa conservação de frutos e grande diversidade de cultivares, o que a torna uma fruteira de boa aceitação pelos agricultores. Além disto, o seu cultivo representa uma atividade altamente rentável, estimada em US $\$ 5.200$ por hectare, e gera emprego no campo, sustentando o trabalho familiar (CASTRO, 2008; KIST, 2012). Para o mercado consumidor, suas características nutricionais têm influência positiva, pois além do sabor agradável, as ameixas são fontes de nutrientes, fibras e energia, visto que seus elementos são facilmente absorvíveis pelo organismo humano (CASTRO, 2008; KIST, 2012). Entretanto, constata-se insegurança do produtor em atuar neste setor, pois ainda é necessário melhorar alguns dos procedimentos recomendados para a cultura, além de conhecer os fatores que realmente impedem a expansão dos plantios (CASTRO et al., 2003). 
A EMBRAPA (Empresa Brasileira de Pesquisa Agropecuária) juntamente com - MAPA (Ministério da Agricultura, Pecuária e Abastecimento) e o CNPq (Conselho Nacional de Desenvolvimento Científico e Tecnológico) vêm desenvolvendo projetos com o objetivo de incentivar o cultivo dessa fruteira no Brasil. Sabendo-se que o maior problema é a falta de certificação de mudas, estão em execução pela EMBRAPA diversas atividades que têm por objetivo a disponibilização de material propagativo de alta sanidade e com identidade genética, utilizando plantas mantidas em borbulheiras, sob rigoroso controle fitossanitário (CASTRO et al., 2008). Estas atividades visam à implantação de programa de certificação de mudas matrizes de ameixeira. Dentre os problemas fitossanitários alvos merece atenção a doença associada aos fitoplasmas.

\subsubsection{Fitoplasmas}

Fitoplasmas são organismos procariotos, sem parede celular, sendo a célula circundada somente por uma membrana plasmática, apresentando tamanho variável de 200 a 800 nm, reprodução por fissão celular ou gemulação. Quando presentes nas células vegetais são visualizados, ao microscópio eletrônico de transmissão, como corpúsculos arredondados, elípticos, clavados ou alongados (BEDENDO, 2011). Acredita-se que esses organismos divergiram de um ancestral Gram positivo, através da redução do genoma e da perda da parede celular (HOGENHOUT et al., 2010).

Esses patógenos estão relacionados com as doenças genericamente conhecidas como amarelos ("yellows"). Inicialmente, acreditava-se que essas doenças eram causadas por vírus, devido aos sintomas apresentados pelas plantas doentes e também pela forma de transmissão do agente causal por insetos (BERTACCINI et al., 2009). Em 1967, observando tecidos de plantas doentes ao microscópio eletrônico, pesquisadores japoneses evidenciaram a presença de corpúsculos arredondados semelhantes aos já conhecidos micoplasmas patogênicos aos animais (DOI et al., 1967). Esses microrganismos foram identificados como MLOs ("Mycoplasma Like Organisms") e a partir de 1994, o termo fitoplasma passou a ser empregado para designar esses patógenos vegetais (BEDENDO, 2011). Atualmente, os fitoplasmas estão classificados no SuperReino Prokaria, Reino Monera, Domínio Bacteria, Filo Tenericutes, Classe Mollicutes, 
Ordem Acholeplasmatales, Gênero 'Candidatus Phytoplasma' (NATIONAL CENTER FOR BIOTECHNOLOGY INFORMATION - NCBI, 2015).

Os fitoplasmas, durante o progresso da doença, colonizam os vasos do floema, distribuindo-se de forma sistêmica pela planta (DAVIS; LEE, 2000). Os sintomas exibidos pelas plantas infectadas aparentam ser causados por distúrbio no balanço hormonal do hospedeiro. São induzidos por esses patógenos os sintomas de clorose (amarelecimento), superbrotamento de ramos, enfezamento generalizado na planta, filodia (transformação de órgãos florais em estruturas foliares), virescência (desenvolvimento de cloroplasto em órgãos florais), avermelhamento foliar, necrose dos vasos, declínio e, consequentemente, morte da planta (DAVIS; LEE, 2000).

Algumas doenças associadas aos fitoplasmas têm se mostrado bastante destrutivas. No âmbito mundial pode-se citar o superbrotamento da batata, o declínio da pereira, os amarelos da videira, o nanismo do arroz, os amarelos do pessegueiro e o amarelo letal do coqueiro (DAVIS, 1995). No Brasil, as doenças que merecem destaque são o enfezamento do milho, enfezamento do repolho, couve-flor e brócolis, além da síndrome do amarelecimento foliar da cana-de-açúcar, associada a um complexo formado por um vírus e um fitoplasma, o que acarretou perdas relevantes para essa cultura (BEDENDO, 2011). Recentemente, os fitoplasmas também foram associados aos sintomas de Huanglongbing nos citros. Essa associação foi relatada na China e no Brasil (TEIXEIRA et al., 2009).

A diagnose de doenças e a detecção desses patógenos foram inicialmente realizadas por microscopia eletrônica de transmissão ou varredura. Essa técnica permite evidenciar a presença de fitoplasmas nas plantas, mas devido à exigência de alta qualificação dos operadores de microscópio e ao alto custo do equipamento, o uso rotineiro da mesma torna-se pouco viável nas pesquisas com este tipo de agente patogênico (BARROS, 2002). Com o advento e o progresso das metodologias moleculares, estas passaram a ser utilizadas correntemente nas investigações, proporcionando um grande avanço nos estudos dos fitoplasma (LEE et al., 1998).

A técnica de PCR ("Polimerase Chain Reaction"), conduzida com primers universais ou específicos derivados das sequências nucleotídicas do gene $16 \mathrm{~S}$ rDNA, tem se mostrado sensível e confiável para a detecção de fitoplasmas (LEE et al., 1998). Esta técnica, aliada à técnica molecular de RFLP ("Restriction Fragment Lenght Polymorphisms"), tem sido amplamente empregada para a caracterização de 
fitoplasmas, permitindo a determinação de um esquema de classificação, o qual tem sido internacionalmente aceito para separar distintos fitoplasmas ao nível de grupos e subgrupos (LEE et al., 1998). Mais recentemente, programas computacionais foram desenvolvidos para análise de RFLP, a partir do sequenciamento da região do gene $16 \mathrm{~S}$ rDNA. Esses programas têm contribuído para a expansão desse esquema de classificação, se constituindo em ferramentas mais acuradas para a identificação da diversidade genética existente entre os fitoplasmas (WEI et al., 2007, ZHAO et al., 2009). A aplicação de técnicas moleculares na classificação de fitoplasmas é justificada pelo fato destes microrganismos não serem cultiváveis em meio de cultura, o que impede a caracterização morfológica e fisiológica dos mesmos. Este impasse resulta na impossibilidade de atender aos requisitos exigidos para a classificação taxonômica de microrganismos que usa a nomenclatura binomial latina. Assim, a classificação dos fitoplasmas vem sendo feita temporariamente ao nível taxonômico de espécie "Candidatus" ('Ca') (DAVIS; LEE, 2000).

\subsubsection{Um fitoplasma do grupo 16SrI encontrado em ameixeira e em outras espécies vegetais ocorrentes no Brasil}

Os fitoplasmas vêm sendo reconhecidos como agentes de perdas expressivas em diversas culturas, incluindo as fruteiras temperadas, as quais compreendem o gênero Prunus, como as ameixeiras. Considerando-se que as espécies dessa frutífera cultivadas no Brasil são exóticas e que foram introduzidas a partir de material propagativo originário de grandes centros mundiais produtores, existia a suspeita de que esse patógeno estivesse presente em pomares instalados no território brasileiro. Esse pressuposto foi evidenciado em 2013, quando árvores de plantios comerciais localizados em Paranapanema (SP) foram observadas exibindo típicos sintomas induzidos por fitoplasmas. Os sintomas eram similares àqueles relatados em outros países, caracterizados por superbrotamento de ramos, redução do comprimento de entrenós, além de amarelecimento, deformação, redução do tamanho de folhas e declínio da planta (Figura 1) (FLÔRES, 2013). Amostras dessas plantas foram coletadas e a detecção de fitoplasmas foi positiva em 27 das 60 plantas sintomáticas analisadas, indicando que estes agentes estavam presentes em $45 \%$ das plantas suspeitas de infecção. Este achado se tornou o primeiro relato da doença 'amarelo da ameixeira' no Brasil. A identificação 
do fitoplasma, conduzida por meio de PCR com primers específicos, clonagem, sequenciamento e análise de sequências nucleotídicas, apontou que o mesmo era um representante do grupo 16SrI-B (FLÔRES, 2013).
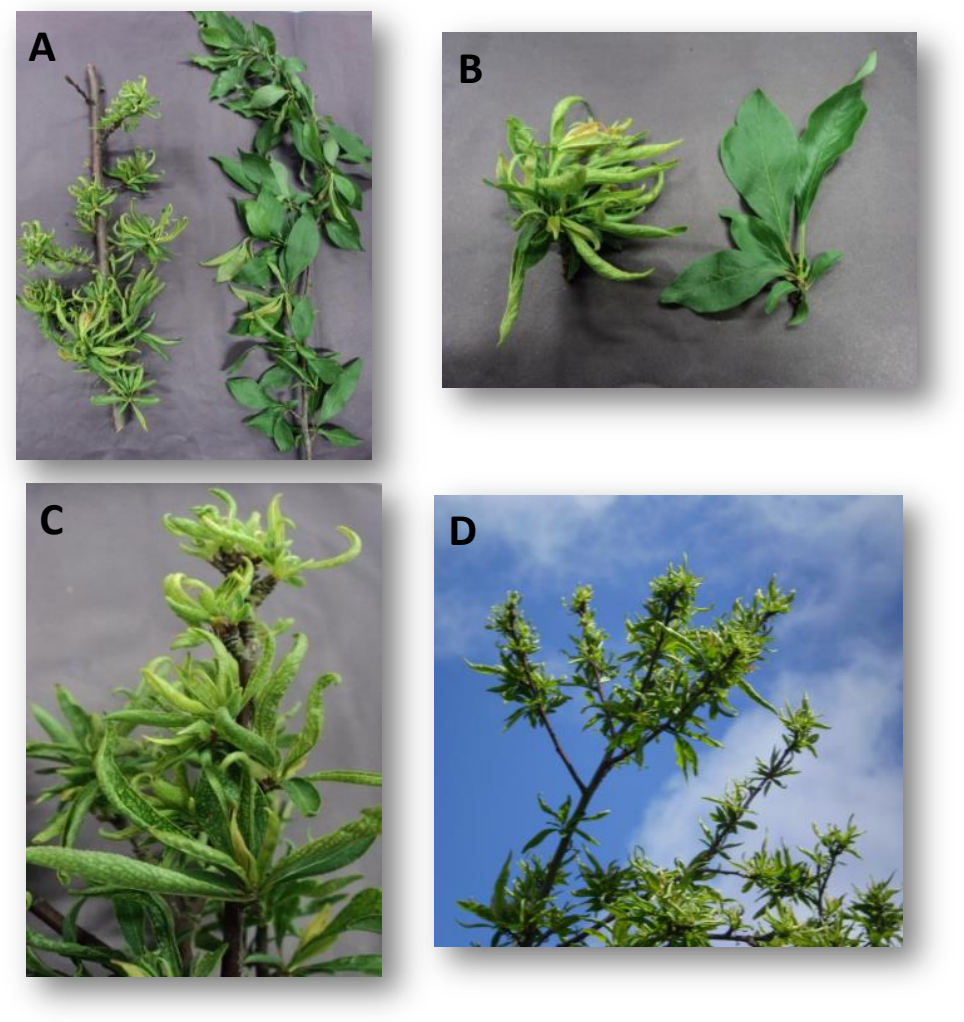

Figura 1 - Sintomas de fitoplasmas em plantas de ameixeira: A. Ramo com superbrotamento (à esquerda) e ramo assintomático (à direita), B. Sintomas de redução de tamanho foliar (à esquerda) e folhas normais (à direita), C. Sintomas de clorose e retorcimento de folhas, D. Sintoma de superbrotamento e redução no tamanho de folhas. (fotos gentilmente cedidas pela Dra Daniela Flôres)

No Brasil, doenças importantes causadas por fitoplasmas do grupo 16SrI têm sido relatadas em diversos patossistemas, sendo a principal delas o enfezamento vermelho do milho, no qual ocorrem sintomas de avermelhamento intenso e generalizado das folhas, redução no porte da planta, afinamento de colmos, redução na produção de grãos e, algumas vezes, proliferação de espigas. A doença prejudica o desenvolvimento das espigas e dos grãos, que podem apresentar-se pequenos, manchados, frouxos na espiga ou chochos, devido ao seu enchimento incompleto (OLIVEIRA et al.,2005). A doença pode ocorrer com até $100 \%$ de incidência e provocar severos danos à cultura, em plantios feitos com material suscetível em condições favoráveis ao patógeno e ao seu vetor (OLIVEIRA et 
al.,2005). Outras plantas também já foram identificadas no Brasil como hospedeiras desse grupo de fitoplasma, entre elas a cana-de-açúcar (Saccharum sp.), a soja (Glycine max L.), o coqueiro (Cocos nucifera), brássicas (Brassica oleraceae), maracujazeiro (Passiflora edulis f. flavicarpa), videira (Vitis vinifera), dendezeiro (Elaeis guineenses), além de plantas ornamentais como primavera (Boungainvillea spectabilis) e espécies daninhas como buva (Erigeron bonariensis). (BRIOSO, 2003; AMARAL MELO, 2007; ECKSTEIN, 2010; MONTANO; CUNHA JUNIOR; PIMENTEL, 2011; PEREIRA, 2011).

\subsubsection{Fitoplasmas em Prunus sp.}

Os fitoplasmas possuem uma grande diversidade de espécies hospedeiras em razão da sua alta diversidade genética. Devido a esses fatores, representantes de outros grupos de fitoplasmas, diferentes daquele encontrado no Brasil, já foram relatados em associação com fruteiras do gênero Prunus.

$\mathrm{Na}$ Europa a doença causada por fitoplasmas é conhecida como "Amarelo das fruteiras de caroço" e tem provocado grandes perdas econômicas, devido à alta mortalidade de árvores infectadas (JARAUSCH; JARAUSCH, 2010). Um fitoplasma classificado como 'Candidatus Phytoplasma prunorum', pertencente ao grupo 16SrX, tem sido associado à doença que tem sido registrada em uma série de fruteiras temperadas, como ameixeira, damasqueiro, pessegueiro, cerejeira, dentre outras (JARAUSCH; JARAUSCH, 2010). Dentre as espécies de plantas do gênero Prunus, oito espécies 'Candidatus', já foram relatadas em associação com as mesmas, como segue: 'Ca P. pronurum' (grupo 16SrX-B), 'Ca P. mali', (grupo 16SrX-A), 'Ca P. pyri' (grupo 16SrX-C), 'Ca P. asteris' (grupo 16SrI), 'Ca P. aurantifolia' (grupo 16SrII), 'Ca P. ziziphi (grupo 16SrV), 'Ca P. fraxini' (grupo 16SrVII), 'Ca P. phoenicium' (grupo 16SrIX), 'Ca P. pruni' (grupo 16SrIII), 'Ca P. solani' (grupo 16SrVII) (CIESLINSKA, 2011; FLÔRES, 2013).

$\mathrm{Na}$ Europa e na Ásia Menor, árvores de damasqueiro são perdidas anualmente, devido à infecção por ' $\mathrm{Ca} \mathrm{P}$. pronurum'. O declínio da pereira, uma das doenças de natureza fitoplasmática mais destrutivas que se conhece, causada por 'Ca P. pyri', tem sido relatada nos Estados Unidos, Europa, Ásia Menor e Taiwan (FOISSAC; WILSON, 2010). A doença denominada vassoura de bruxa da amendoeira, a qual provoca danos significativos à cultura, está associada com a 
presença de 'Ca P. phoenicium', tendo sido relatada pela primeira vez no Líbano (VERDIN et al., 2003). A proliferação de ramos da macieira, também é uma doença de etiologia fitoplasmática. O agente causal é o 'Ca P. mali', com ocorrência frequente em diversos países da Europa e na Turquia, ocasionando perdas de rendimento, devido à redução na produtividade e qualidade comercial dos frutos (FOISSAC; WILSON, 2010).

Recentemente, um fitoplasma pertencente ao grupo $16 \mathrm{SrV}$ foi associado a plantas pertencentes a diversas espécies de fruteira temperadas cultivadas comercialmente na América do Norte, Europa e Ásia. Dentre essas plantas, algumas são do gênero Prunus, como pessegueiro, cerejeira doce e nespereira (LI et al., 2014; WANG et al., 2014). Na Argentina, também foi relatada a ocorrência de infecção fitoplasmática em pomares de pessegueiro instalados na província de Jujuy (FERNÁNDEZ et al., 2013). Os sintomas observados nas árvores infectadas se caracterizavam pelo amarelecimento e necrose das folhas, encurtamento de internódios e desfolha prematura. Análises de sequências do gene 16S rDNA, revelaram que esse fitoplasma pertence ao grupo 16 SrIII.

Fitoplasmas afiliados ao grupo 16SrI, um grupo cujos representantes estão amplamente distribuídos no mundo, têm sido frequentemente associados a doenças observadas em fruteiras de caroço. Recentemente na China, fitoplasmas desse grupo foram encontrados em cerejeira (Prunus cerasifera Ehrh) e em pessegueiro (Prunus persica L.), causando sintomas semelhantes àqueles observados em ameixeiras cultivadas no Brasil (ZHANG et al., 2013; LI et al., 2014). Em vários países da Europa, representantes desse grupo foram relatados em associação com uma doença conhecida como enrolamento clorótico da folha de damasqueiro (SCHNEIDER et al., 1993). Na Itália e na República Tcheca, fitoplasmas do grupo 16SrI vêm causando severos danos em pessegueiro, damasqueiro, ameixa europeia e cerejeira doce, sendo os sintomas caracterizados principalmente por enfezamento, amarelecimento de folhas e redução do vigor da planta (LEE et al., 1998; FIALOVÁ et al., 2004).

\subsubsection{Colonização e flutuação sazonal dos fitoplasmas em plantas lenhosas}

A colonização e concentração de fitoplasmas, principalmente em plantas lenhosas, como aquelas do gênero Prunus, ainda são pouco estudadas. Sabe-se 
que embora a infecção desse patógeno seja sistêmica, ou seja, o fitoplasma é conduzido junto com a seiva, nem sempre a sua distribuição na planta é uniforme. A concentração desse patógeno no tecido pode ser diferenciada, dependendo da parte da planta (BEDENDO, 2011).

$\mathrm{Na}$ maioria das espécies lenhosas, a concentração de fitoplasmas na parte aérea está sujeita a flutuações sazonais. Errea et al., 2002, verificou a movimentação sazonal de fitoplasmas em plantas de macieira e pereira que apresentavam proliferação de ramos (PM) e declínio (DP), causadas por 'Candidatus Phytoplasma mali' e 'Candidatus Phytoplasma prunorum', respectivamente. Utilizando microscopia de fluorescência (DAPI), foi possível observar que os fitoplasmas desapareciam da parte aérea da planta durante o período de inverno, porém foram encontrados, nesse mesmo período, sobrevivendo nas raízes. A razão pela qual os fitoplasmas se comportam dessa maneira é devido à inativação e degeneração dos tubos floemáticos durante o rigoroso inverno europeu. Sendo assim, estes microrganismos são eliminados da parte aérea durante o inverno. No entanto, estes procariotos sobrevivem nas raízes, onde os vasos permanecem intactos durante todo o ano e conseguem recolonizar a planta após o período de dormência da mesma. A eliminação dos fitoplasmas na parte aérea foi confirmada também através de testes de enxertia que foram feitos logo após o inverno, pois não ocorreu a transmissão do patógeno para as plantas enxertadas (MARCONE, 2010).

O modelo de colonização dos agentes da PM e do DP foi constatado também em plantas do gênero Ulmaceae (JARAUSCH et al., 1999). Ainda, Baric e colaboradores (2011) também demonstraram, através da quantificação de fitoplasmas em tecidos vegetais de macieira, a presença de maior título do patógeno nas raízes durante o período de inverno. Em contrapartida, vários trabalhos relataram a presença de fitoplasmas na parte aérea mesmo durante o período de dormência da planta. Para os fitoplasmas da espécie 'Candidatus Phytoplasma prunorum', agente causal do amarelo das fruteiras de caroço, foi constatado que o mesmo permanece na parte aérea da ameixeira e do damasqueiro durante o período de inverno, além de permanecerem durante todo ano nos tecidos das raízes (JARAUSCH et al., 1999, ERREA et al., 2002; MARCONE, 2010). Esse mesmo modelo de colonização foi observado em plantas do gênero Alnus (MARCONE, 2010). Em pessegueiros cultivados na região do Mediterrâneo, o fitoplasma 'Candidatus Phytoplasma pyri' persiste na parte aérea do pessegueiro mesmo 
durante o inverno, porém tal fato não ocorre na região central da Europa, onde 0 inverno é mais rigoroso (GARCIA-CHAPA et al., 2003).

Os trabalhos publicados sobre esse assunto sugerem a ocorrência de flutuação sazonal do patógeno na planta, ou seja, a temperatura parece influenciar tanto na movimentação quanto na multiplicação dos fitoplasmas. São poucos os estudos que tratam da influência da temperatura no ciclo de vida desse patógeno. No Brasil, para o patossistema milho-enfezamento vermelho, doença associada a um fitoplasma do grupo $16 \mathrm{SrI}$, foi evidenciado que temperaturas elevadas (19-30ㅇ) podem influenciar a incidência do enfezamento e a transmissão do fitoplasma (SABATO; LANDAU, 2010). Informações desta natureza para os diversificados patossistemas envolvendo fitoplasmas pode contribuir para compreensão de aspectos relacionados à epidemiologia, estabelecimento de metodologias para seleção de materiais resistentes, entendimento das relações patógeno-vetor e condução de diagnoses mais seguras e confiáveis das doenças, visando implementar programas mais eficientes de manejo.

\subsubsection{Reação em Cadeia da Polimerase em tempo real (qPCR)}

$\mathrm{O}$ advento da biologia molecular foi certamente um dos maiores passos da ciência durante o século XX. A descoberta da Reação em Cadeia da Polimerase (PCR) trouxe enormes benefícios e progressos científicos como sequenciamento de genomas, a expressão de genes em sistemas recombinantes, o estudo da genética molecular e a comprovação rápida de doenças infecciosas (NOVAIS; ALVES, 2004). Recentemente, uma inovação tecnológica resultante da PCR, denominada de PCR em tempo real (qPCR), vem ganhando espaço nos laboratórios de pesquisa por apresentar como característica a geração de resultados quantitativos. Essa nova técnica permite o acompanhamento da reação em tempo real e a apresentação dos resultados de forma mais rápida, sensível e precisa, em relação à $P C R$ convencional que apresenta somente resultados qualitativos (NOVAIS; ALVES, 2004).

Trabalhos envolvendo a utilização da técnica de qPCR, para deteç̧ão e quantificação de fitoplasmas em seus hospedeiros são encontrados na literatura desde há alguns anos (GALETTO; MARZACHI, 2010). Alguns pontos que desfavorecem a detecção desses patógenos pelos métodos convencionais fizeram com que essa nova técnica fosse introduzida como rotina de laboratório. Dentre 
esses pontos podem ser destacados a distribuição desuniforme desses patógenos nas plantas e sua multiplicação nos tecidos vegetais, que variam de acordo com o estádio fenológico do hospedeiro e as condições climáticas (GALETTO; MARZACHI, 2010). Além disso, principalmente em plantas decíduas, os fitoplasmas podem aparecer em baixas concentrações nos tecidos vegetais, comprometendo sua detecção e dificultando sua identificação molecular (JAWHARI et al., 2015).

Estudos recentes têm demonstrado que a técnica de qPCR apresenta maior sensibilidade, eficiência, rapidez, qualidade e confiabilidade em seus resultados, principalmente para quantificação e detecção de fitoplasmas em plantas lenhosas. JAWHARI e colaboradores (2015), utilizando GPCR, conseguiram quantificar o fitoplasma da espécie 'Candidatus Phytoplasma phoenicium' em raízes e folhas de plantas de pessegueiro e nectarineira. Em cerejeira, fitoplasmas causadores da 'doença $X$ ' foram quantificados através dessa nova técnica, pela aplicação de um protocolo rápido, sensível e específico (HUANG et al., 2014). Outros estudos também têm comprovado a eficiência dessa nova técnica para fins de diagnose e investigações sobre a distribuição sazonal de fitoplasmas em hospedeiros portadores de relevantes doenças, como a proliferação de ramos da macieira, doença da raiz em coqueiro, "Bois noir" em videira, declínio da pereira e o amarelo das fruteiras de caroço (TORRES et al., 2005; ALDAGHI et al., 2007; HREN et al., 2007; MANIMEKALAI et al., 2011; BARIC et al., 2011; BARIC, 2012). A técnica de PCR quantitativo também vem sendo utilizada para melhor entendimento das relações patógeno-vetor. Essa técnica permite calcular a concentração de fitoplasmas em seus vetores e, consequentemente, determinar sua multiplicação no inseto ao longo do tempo, logo após sua aquisição pelo mesmo (BOSCO et al., 2007; MARTINI et al., 2007).

Diagnoses de doenças de origem fitoplasmática conduzidas com a técnica de qPCR têm um futuro promissor, sobretudo para programas fitossanitários que visam a inspeção de mudas produzidas em viveiros comerciais, uma vez que a utilização de mudas certificadas e sadias é uma das principais formas de controle das doenças causadas por este tipo de patógeno (GALETTO; MARZACHI, 2010). 


\section{MATERIAL E MÉTODOS}

\subsubsection{Montagem do ensaio e coleta das amostras}

Foram utilizadas plantas de duas variedades de ameixeira japonesa, Golfblaze e Azteca, cultivadas em pomares comerciais identificados pelos algarismos I e II, respectivamente (Figura 2), ambos localizados na região de Paranapanema, SP (Tabela 1).
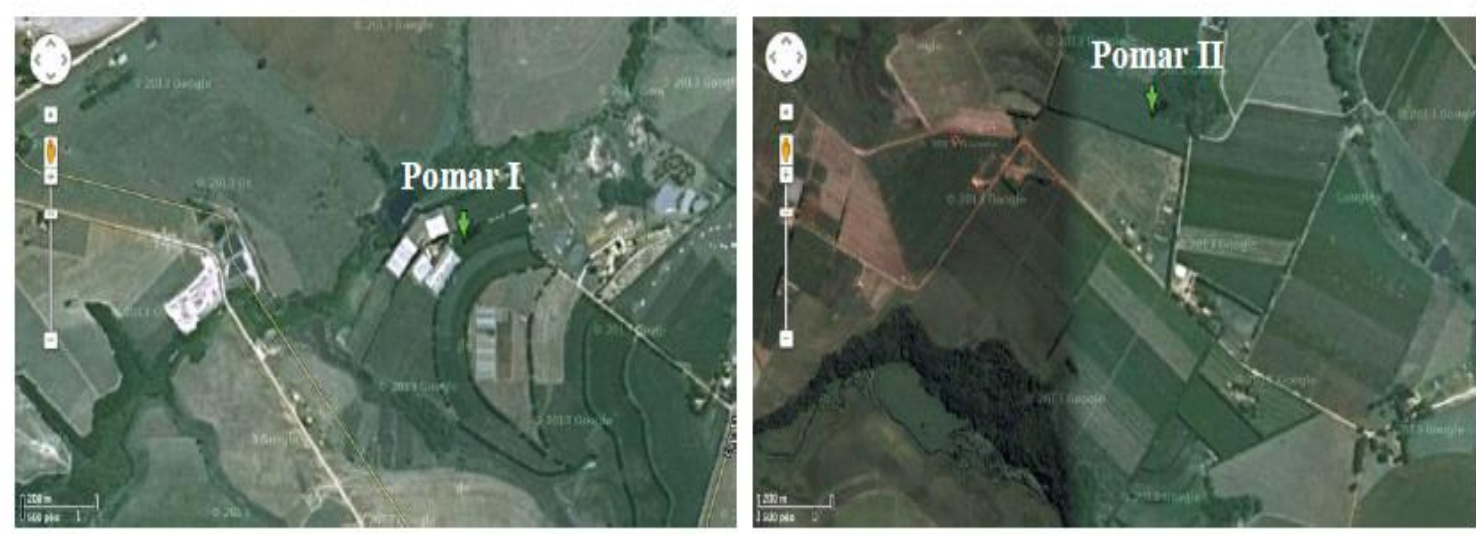

Figura 2 - Localização dos pomares I e II em Paranapanema-SP. Fonte: FLÔRES, 2013

Tabela 1- Localização e principais características dos pomares de ameixeira amostrados em Paranapanema SP. Fonte: FLÔRES, 2013

\begin{tabular}{ccccc}
\hline Área & Latitude & Longitude & Altitude & $\begin{array}{c}\text { Ano de } \\
\text { plantio }\end{array}$ \\
\hline Pomar I & $23^{\circ} 27^{\prime 2} 20,98^{\prime \prime} S$ & $48^{\circ} 53^{\prime} 42,40^{\prime \prime} \mathrm{O}$ & $580 \mathrm{~m}$ & 1998 \\
Pomar II & $23^{\circ} 27^{\prime} 45,66^{\prime \prime} S$ & $48^{\circ} 44^{\prime} 57,34^{\prime \prime} \mathrm{O}$ & $628 \mathrm{~m}$ & 2006 \\
\hline
\end{tabular}

Quatro plantas doentes pertencentes a cada variedade foram amostradas mensalmente durante o período de um ano (setembro de 2012 a agosto de 2013). As amostragens foram realizadas considerando-se os períodos de desenvolvimento das plantas e os ciclos vegetativos das mesmas, compreendendo dormência, mobilização de reserva, brotação, floração, frutificação, maturação dos frutos e queda das folhas. Em cada mês foram tomadas duas amostras de raiz localizadas em partes opostas do sistema radicular e três amostras da parte aérea em diferentes alturas (aproximadamente 1,0 m, 1,5 m e 2,0 m) em relação ao solo (Figura 3). 


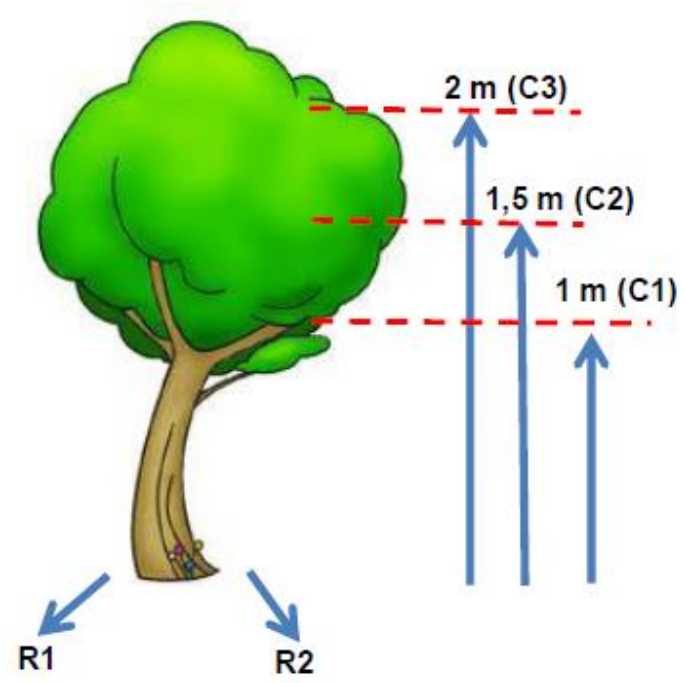

Figura 3 - Representação esquemática de uma árvore de ameixeira, ilustrando a forma de coleta de amostras. A letra $\mathbf{C}$ corresponde à copa e $\mathbf{R}$ à raiz (R1 e R2: lados opostos do sistema radicular) Fonte: FLÔRES, 2013

\subsubsection{Extração de DNA total}

Para realizar a etapa de extração total de DNA, foi utilizado o protocolo descrito por DOYLE, 1990. Material vegetal de cada amostra (2 gramas) foi macerado em nitrogênio liquido, em almofariz de porcelana. Uma parte do macerado foi transferida para microtubos de $1,5 \mathrm{~mL}$ e ao macerado foram adicionados $800 \mu \mathrm{L}$ de tampão de extração $2 \mathrm{X} \mathrm{CTAB}$, à $60^{\circ} \mathrm{C}$, acrescido de $2 \mu \mathrm{L}$ de mercaptanol por $\mathrm{mL}$ de tampão. Após a homogeneização, o material foi incubado à temperatura de $65{ }^{\circ} \mathrm{C}$ por 60 min. Em seguida, foram adicionados $600 \mu \mathrm{L}$ de CIA (clorofórmio-isoamílico, 24:1) em cada amostra, a qual foi homogeneizada em vortex até a formação de uma emulsão. A mistura foi centrifugada a $14.000 \mathrm{rpm}$, durante 10 minutos. Os microtubos foram retirados da centrifuga cuidadosamente, evitando perturbar a interface. Com auxilio de uma pipeta, a parte superior foi transferida para um novo tubo, e, ao sobrenadante, foram adicionados $540 \mu \mathrm{L}$ de isopropanol gelado $\left(-20{ }^{\circ} \mathrm{C}\right)$. Os componentes foram misturados gentilmente para precipitar os ácidos nucléicos e mantidos no freezer $\left(-20^{\circ} \mathrm{C}\right)$ por uma noite. Após essa etapa, as amostras foram centrifugadas a $14.000 \mathrm{rpm}$, durante 10 minutos. Em seguida, o sobrenadante foi descartado, tomando o devido cuidado para não perder o precipitado. O precipitado foi lavado com $1 \mathrm{~mL}$ de etanol $80 \%$ e incubado durante 5 minutos à temperatura ambiente. Após a lavagem, foram adicionados $500 \mu \mathrm{L}$ de $\mathrm{NaCl} 1 \mathrm{M}$, no qual o 
precipitado foi dissolvido e incubado à $4{ }^{\circ} \mathrm{C}$, durante 60 minutos. Após a incubação, as amostras foram centrifugadas novamente (14.000 rpm - 10 minutos) e o sobrenadante foi transferido para um novo microtubo, onde foram adicionados 350 $\mu \mathrm{L}$ de isopropanol gelado $\left(-20^{\circ} \mathrm{C}\right)$. Em seguida, os microtubos foram mantidos por uma noite à $4 \stackrel{\circ}{\circ}$. As últimas etapas desse protocolo consistiram em centrifugar as amostras (14.000 rpm - 10 minutos), descartar o sobrenadante e lavar o precipitado com $1 \mathrm{~mL}$ de etanol $80 \%$, por 1 minuto. Este procedimento foi realizado em duplicata. Os microtubos foram abertos e ficaram sobre papel toalha, à temperatura ambiente, até sua secagem completa. O precipitado foi diluído em $100 \mu \mathrm{L}$ de água miliQ autoclavada e armazenado à $-20{ }^{\circ} \mathrm{C}$ para uso nos testes de qPCR. A quantificação do DNA foi determinada em espectrofotômetro (Nanodrop 1000 Thermo Scientific). O DNA de todas as amostras foi ajustado para concentração de $50 \mathrm{ng}$.

- Tampão de extração 2X CTAB: Componentes: $2 \mathrm{~g}$ de CTAB; $8,18 \mathrm{~g}$ de $\mathrm{NaCl} ; 0,74 \mathrm{~g}$ de EDTA; $1,57 \mathrm{~g}$ de TRIS-HCL; e 1,0g de PVP. Os componentes foram dissolvidos em água miliQ, completando o volume para $100 \mathrm{~mL}$ e ajustando o $\mathrm{pH}$ para 8,0.

\subsubsection{PCR em tempo real}

DNA total extraído das ameixeiras foi utilizado para quantificar o fitoplasma nos tecidos vegetais por meio do PCR quantitativo. As reações foram conduzidas com os pares de primers, UniRNAForward/UniRNAReverse (HREN et al., 2007). As sequências dos primers utilizados encontram-se descritas abaixo:

UniRNA- Forward 5' AAA TAT AGT GGA GGT TAT CAG GGA TAC AG 3' UniRNA- Reverse 5' AAC CTA ACA TCT CAC GAC ACG AAC T 3'

As reações foram realizadas em placas de 96 poços, em termociclador 7500 FAST (Applied Biosystems). Foi utilizado o Kit Platinum SYBR $®$ GEEN qPCR SUPER MIX UDG - Invitrogen. Cada reação de $12,5 \mu \mathrm{L}$ foi composta por $100 \mathrm{ng}$ de DNA vegetal ( $2 \mu \mathrm{L}$ de DNA diluído); 6,25 $\mu \mathrm{L}$ de Supermix (1X); 0,25 $\mu \mathrm{L}$ de cada iniciador (primer); $0,25 \mu \mathrm{L}$ de ROX (1:10); e 3,5 $\mu \mathrm{L}$ de água livre de nucleasse (IDT). As condições de PCR foram: 2 minutos à $50^{\circ} \mathrm{C}, 10$ minutos à $95^{\circ} \mathrm{C}, 40$ ciclos de 15 segundos à $95^{\circ} \mathrm{C}$ e 1 minuto à $60^{\circ} \mathrm{C}$. DNA extraído de uma planta sadia de ameixeira e a água foram utilizados como controles negativos, enquanto o controle positivo foi 
representado por DNA extraído de uma planta de milho comprovadamente portadora do fitoplasma associado ao enfezamento do milho e identificado como pertencente ao subgrupo $16 \mathrm{Srl}-\mathrm{B}$. Em cada reação uma curva padrão de diluição de DNA de fitoplasma foi realizada com o objetivo de relacionar os valores de $\mathrm{Ct}$ (Cycle treshold) das reações de QPCR com diferentes concentrações de DNA puro do fitoplasma, o que permitiu, ao final, estimar a concentração desse patógeno presente nas amostras de DNA de folhas e raízes de ameixeira. As reações foram realizadas em duplicatas.

$\mathrm{Na}$ construção da curva padrão de diluição de DNA do fitoplasma foram utilizadas as concentrações de $10 \mathrm{ng}, 1 \mathrm{ng}, 0,1 \mathrm{ng}, 0,01 \mathrm{ng}, 0,001 \mathrm{ng}$ de DNA puro do patógeno. Para estimar a concentração do patógeno nas amostras, primeiramente as concentrações da curva padrão foram transformadas em número de cópias de fitoplasmas, utilizando a fórmula descrita por Baric e colaboradores (2011), assim expressa: Número de cópias de fitoplasma/100ng DNA total = [concentração de DNA puro do fitoplasma $(\mathrm{g} / \mu \mathrm{L})$ ] / [(tamanho do clone em $\mathrm{pb} \times$ peso médio de $1 \mathrm{pb}$ DNA) $x$ unidade de massa atômica $(\mathrm{g} / \mathrm{u})]$. O tamanho do clone foi considerado a soma do peso molecular do plasmídeo + inserto, sendo o peso médio de $1 \mathrm{pb}$ de DNA igual a 649 e a massa atômica por unidade foi considerada 1,6605 x $10^{-24} \mathrm{~g} / \mathrm{u}$ (APPLIED BIOSYSTEMS, 2009). Em seguida, foi obtida uma curva padrão que relaciona esses diferentes valores de números de cópias do fitoplasma com seus respectivos valores de $\mathrm{Ct}$ (Cycle treshold) (Figura 4).

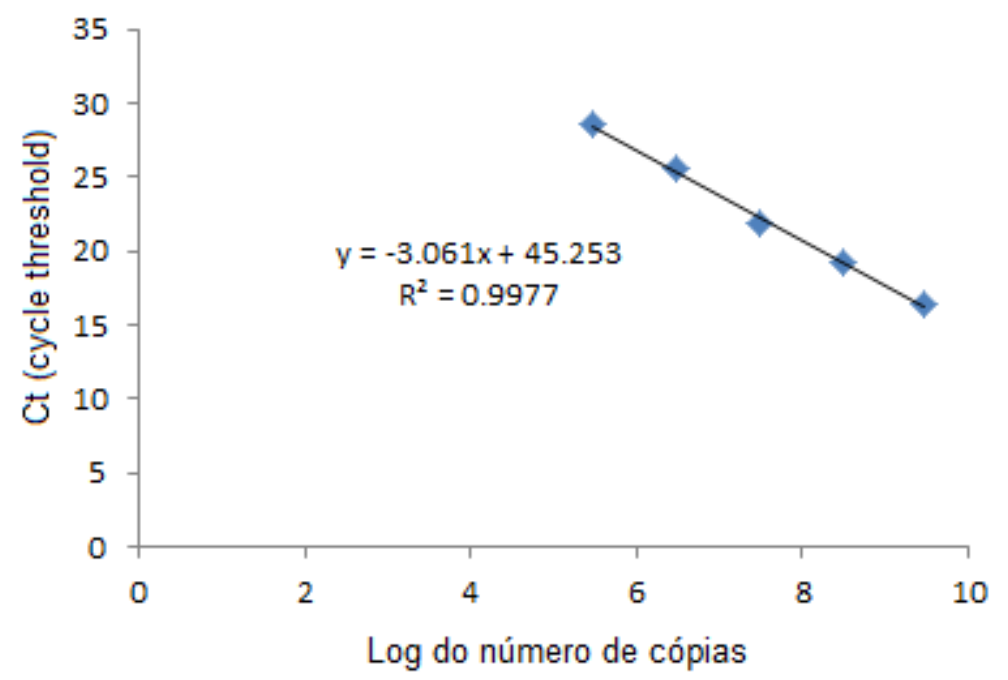

Figura 4 - Curva padrão de correlação entre concentrações conhecidas de DNA (número de cópias de fitoplasma) e valores de $\mathrm{Ct}$. ( $\mathrm{Y}=\mathrm{Ct}$ da amostra e $\mathrm{X}=\log$ número de cópias de fitoplasma/100ng de DNA) 
A variável obtida através dessa correlação foi utilizada na análise de comparação de médias pelo teste de Scott Knot. As análises de variância foram realizadas no programa Assistat versão 7.7, 2014 (SILVA, 2014).

Os produtos gerados pelo qPCR foram analisados por eletroforese em gel de agarose $2 \%$ e tampão TBE $0,5 \mathrm{X}$. A corrida eletroforética foi conduzida com voltagem de $65 \mathrm{~V}$, durante 60 minutos. A coloração dos produtos amplificados foi feita com Syber safe $\AA^{8}$ e, em seguida, a visualização foi processada em transiluminador de ultravioleta. 


\section{RESULTADOS E DISCUSSÃO}

O fitoplasma foi detectado em todas as árvores de ameixeira sintomáticas amostradas, revelando a associação constante entre este patógeno e os sintomas de amarelo característicos da doença. A presença do fitoplasma foi evidenciada pela amplificação de fragmentos de DNA de, aproximadamente, 73 pb (Figura 5), os quais são esperados quando os primers UniRNAF/UniRNAR são empregados nas reações de qPCR (HREN et al., 2007). O produto dessa reação foi purificado e sequenciado e análises realizadas na sequência de DNA, confirmou que o mesmo correspondia a uma sequência nucleotídica encontrada em fitoplasma. O patógeno foi encontrado tanto nas amostras originárias da parte aérea, representadas pelas folhas, como nas amostras obtidas da parte subterrânea, representadas pelos tecidos das raízes. Esses resultados evidenciaram claramente que o patógeno permaneceu infectando a planta durante todos os períodos do ano em que as amostras foram coletadas. No entanto, as análises mostraram que ocorreram variações na concentração de fitoplasma na planta durante as diferentes estações do ano, sugerindo que a colonização do hospedeiro pelo patógeno sofre influência da época do ano. Essa variação também foi observada em relação às diferentes fases do ciclo vegetativo da planta, como pode ser observado na Tabela 2. Pesquisas conduzidas com a doença conhecida como amarelo da videira, também associada a um fitoplasma, revelaram resultados similares àqueles obtidos no presente estudo, evidenciando que a detecção de fitoplasma pode variar em função das diferentes partes da planta amostradas, bem como com o estádio fenológico da planta em que as amostras são coletadas (DEL SERRONE; BARBA, 1996). Recentemente, um trabalho que analisou o patossistema ameixeira-fitoplasma também relatou que a época do ano pode ter efeito sobre a concentração do patógeno nos tecidos do hospedeiro (FLÔRES, 2013), mostrando a existência de uma perfeita concordância com os dados resultantes da investigação desenvolvida no presente trabalho de pesquisa. 


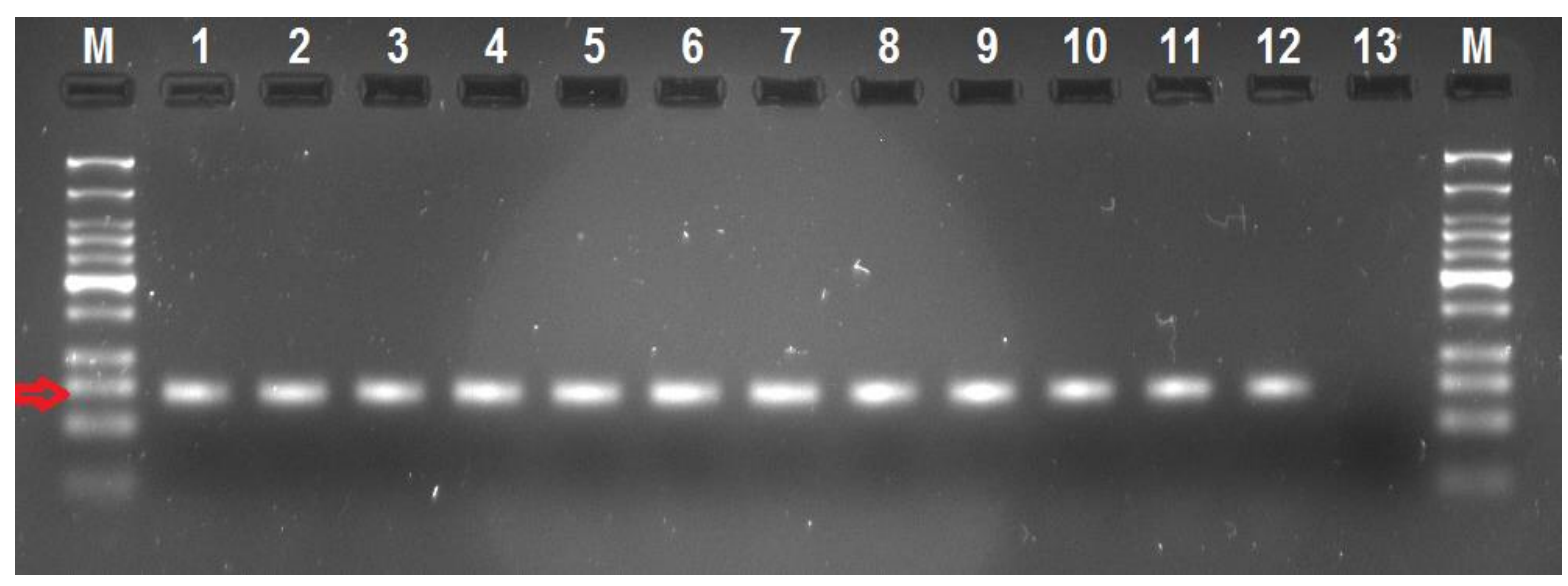

Figura 5 - Gel de agarose referente às reações amplificadas do qPCR. As amostras de 1 a 11 indicam plantas sintomáticas de ameixeira. As amostras 12 e 13 são os controles positivo (fitoplasma do milho) e negativo (água), respectivamente. A seta vermelha indica 73pb, M - marcador peso molecular (Low Molecular Weight DNA Ladder)

Os resultados mostraram que a concentração de fitoplasma variou de 5,3 $x$ $10^{3}$ a $4,54 \times 10^{6}$ e de $3,28 \times 10^{3}$ a $1,28 \times 10^{6}$ número de cópias/100ng de DNA total, na parte aérea e nas raízes, respectivamente (Tabela 2), considerando-se que 100ng de DNA corresponde a $2 \mu \mathrm{L}$ de DNA total e 2 gramas de tecido vegetal. Resultados semelhantes foram relatados em outros trabalhos envolvendo estudos de quantificação de fitoplasma em plantas. Assim, em plantas de vinca e álamo a concentração de fitoplasma variou de $2,2 \times 10^{8}$ a $1,5 \times 10^{9}$ células por grama de tecido (BERGES et al., 2000). Em fruteiras temperadas, como pessegueiro e nectarineira, a concentração de 'Candidatus Phytoplasma phoenicium' variou de $10^{5}$ a $10^{6}$ cópias de fitoplasmas por reação (JAWHARI et al., 2014). Em ameixeira japonesa a concentração de fitoplasma variou de $5,77 \times 10^{5}$ a 3,92 × $10^{9}$ número de cópias/100ng de DNA total, de acordo com o discutido no trabalho de Flôres, 2013. Torres e colaboradores, 2005 quantificaram fitoplasma em tecidos de plantas de ameixeira, pereira e damasqueiro e estimaram a concentração em $9,7 \times 10^{3}$ a 3,0 $x$ $10^{5}$ fitoplasmas por grama de tecido. 'Candidatus Phytoplasma mali', agente causal da proliferação de ramos em macieira, também teve sua concentração estimada, apresentando valores variáveis de 732 a 2,5 x 10 $0^{5}$ (BARIC et al., 2011). 
Tabela 2 - Concentração de fitoplasma (média total) em tecidos foliares e radiculares de ameixeira em distintas épocas do ano e diferentes ciclos vegetativos da planta. Concentração = número de cópias/100ng DNA total

\begin{tabular}{|c|c|c|c|c|c|c|c|c|c|c|c|c|}
\hline & \multicolumn{12}{|c|}{ Época de coleta } \\
\hline & set $/ 12$ & out 12 & nov/12 & $\mathrm{dez} / 12$ & $\mathrm{jan} / 13$ & fev/13 & $\mathrm{mar} / 13$ & $a b r / 13$ & mail/13 & jun $/ 13$ & $\mathrm{jul} / 13$ & ago/13 \\
\hline Amostras & \multicolumn{6}{|c|}{ Presença de folhas } & \multicolumn{6}{|c|}{ Ausência de folhas } \\
\hline Média copa & $7,62 \times 10^{4}$ & $2,51 \times 10^{4}$ & $1,21 \times 10^{5}$ & $4,54 \times 10^{6}$ & $2,89 \times 10^{4}$ & $8,76 \times 10^{3}$ & $5,30 \times 10^{3}$ & $1,40 \times 10^{4}$ & $1,13 \times 10^{4}$ & $1,17 \times 10^{4}$ & $1,09 \times 10^{4}$ & $1,64 \times 10^{4}$ \\
\hline Média raiz & $2,05 \times 10^{4}$ & $1,70 \times 10^{4}$ & $4,98 \times 10^{4}$ & $1,28 \times 10^{6}$ & $2,19 \times 10^{4}$ & $3,28 \times 10^{3}$ & $6,54 \times 10^{3}$ & $4,0 \times 10^{3}$ & $2,11 \times 10^{4}$ & $8,52 \times 10^{3}$ & $9,42 \times 10^{3}$ & $2,12 \times 10^{4}$ \\
\hline Ciclo vegetativo & Brotação & Floração & & Frutificação & & & Maturação & dos frutos & & Dorm & ência & Reserva \\
\hline
\end{tabular}

A análise de variância dos efeitos da variedade, parte da planta (copa ou raiz) e época de amostragem, mostrou diferença significativa na concentração do patógeno para todos os fatores avaliados e para a interação parte da planta versus época de amostragem (Tabela 3).

Considerando o efeito das variedades e parte da planta, observou-se uma maior concentração de fitoplasma na variedade Gulfblaze e na parte aérea (copa). A variedade Gulfblaze apresentou uma concentração média total de 4,23 × $10^{4}$ número de cópias de fitoplasma/100ng de DNA total, enquanto a concentração em Azteca foi estimada em 3,00 × $10^{4}$ número de cópias de fitoplasma/100ng de DNA total. Ambas as variedades possuem o mesmo ciclo vegetativo e as mesmas características fisiológicas, não existindo, aparentemente, nenhuma diferença entre elas que explique a diferença encontrada na concentração de fitoplasma. Alguns autores como Barbosa, 2015 relataram que a variedade Gulfblaze é bastante produtiva e que por isso vem sendo a principal escolha dos produtores brasileiros para a implantação de pomares de ameixeira. Sendo assim, a presença constante do fitoplasma e dessa variedade do hospedeiro no mesmo ambiente ao longo dos anos, pode ter ocasionado uma melhor adaptação desse patógeno a essa variedade e, consequentemente, o aumento da sua multiplicação na mesma. Analisando também as características com relação aos pomares de ameixeira amostrados, como época de plantio, nota-se que o pomar plantado com a variedade Gulfblaze é oito anos mais velho do que o pomar onde está plantado a variedade Azteca. Esse aspecto pode se constituir num fator que possivelmente explicaria essa diferença na concentração de fitoplasma, pois as árvores do pomar implantado primeiro estariam expostas por mais tempo ao patógeno, o qual, consequentemente, estaria a mais tempo se multiplicando na planta. 
Tabela 3 - Análise de variância dos efeitos da variedade (Var), parte da planta (copa ou raiz - C/R) e época de amostragem (EP) na concentração do patógeno. $\mathrm{e}^{\text {ns }}=$ não significativo ( $p>=.05)$; $\quad$ significativo ao nível de $5 \%$ de probabilidade $(.01=<p<.05) ;{ }^{* *}$ significativo ao nível de $1 \%$ de probabilidade $(p<.01)$

\begin{tabular}{ccc}
\hline Fontes de variação & GL & F valores \\
\hline Var & 1 & $6.3100^{*}$ \\
C/R & 1 & $23.4450^{* *}$ \\
EP & 11 & $121.1265^{* *}$ \\
Var $\times$ C/R & 1 & $1.0911^{\mathrm{ns}}$ \\
Var $\times$ EP & 11 & $1.2986^{\mathrm{ns}}$ \\
EP x C/R & 11 & $5.7592^{* *}$ \\
\hline
\end{tabular}

Com relação à diferença na concentração de fitoplasma entre partes da planta, ou seja, parte aérea e raiz, a maior concentração desse patógeno foi encontrada na parte aérea (copa) com uma média total de $4,89 \times 10^{4}$ número de cópias de fitoplasma/100ng de DNA total, enquanto nas raízes a concentração foi de $2,59 \times 10^{4}$ número de cópias de fitoplasma/100ng de DNA total. O Brasil sendo um país tropical, não possui as estações do ano bem definidas e essa característica pode ter contribuído para uma maior concentração do patógeno na parte aérea. Em contraste, nos países europeus onde as estações do ano são bem definidas, com um inverno rigoroso e um verão extremamente quente, os fitoplasmas são encontrados em maior quantidade nas raízes nas épocas mais frias e nas épocas mais quentes a concentração desse patógeno é maior na parte aérea ( $\mathrm{LO}$ et al., 2002; PEDRAZZOLI et al., 2008; BARIC et al., 2011).

Ao analisar as diversas épocas de amostragem, nota-se uma variação na concentração do patógeno ao longo de um ano de avaliação (Tabela 2). Os resultados mostraram a ocorrência de um padrão de colonização do fitoplasma com maior concentração do patógeno nas épocas mais quentes do ano e redução na concentração nas épocas mais frias (Figura 6 e Tabela 2). Isso sugere que a temperatura tem influência sobre a multiplicação do patógeno nos tecidos das plantas, como já havia sido relatado por Oliveira et al., 2010 para o patossistema millho-fitoplasma do enfezamento vermelho. 


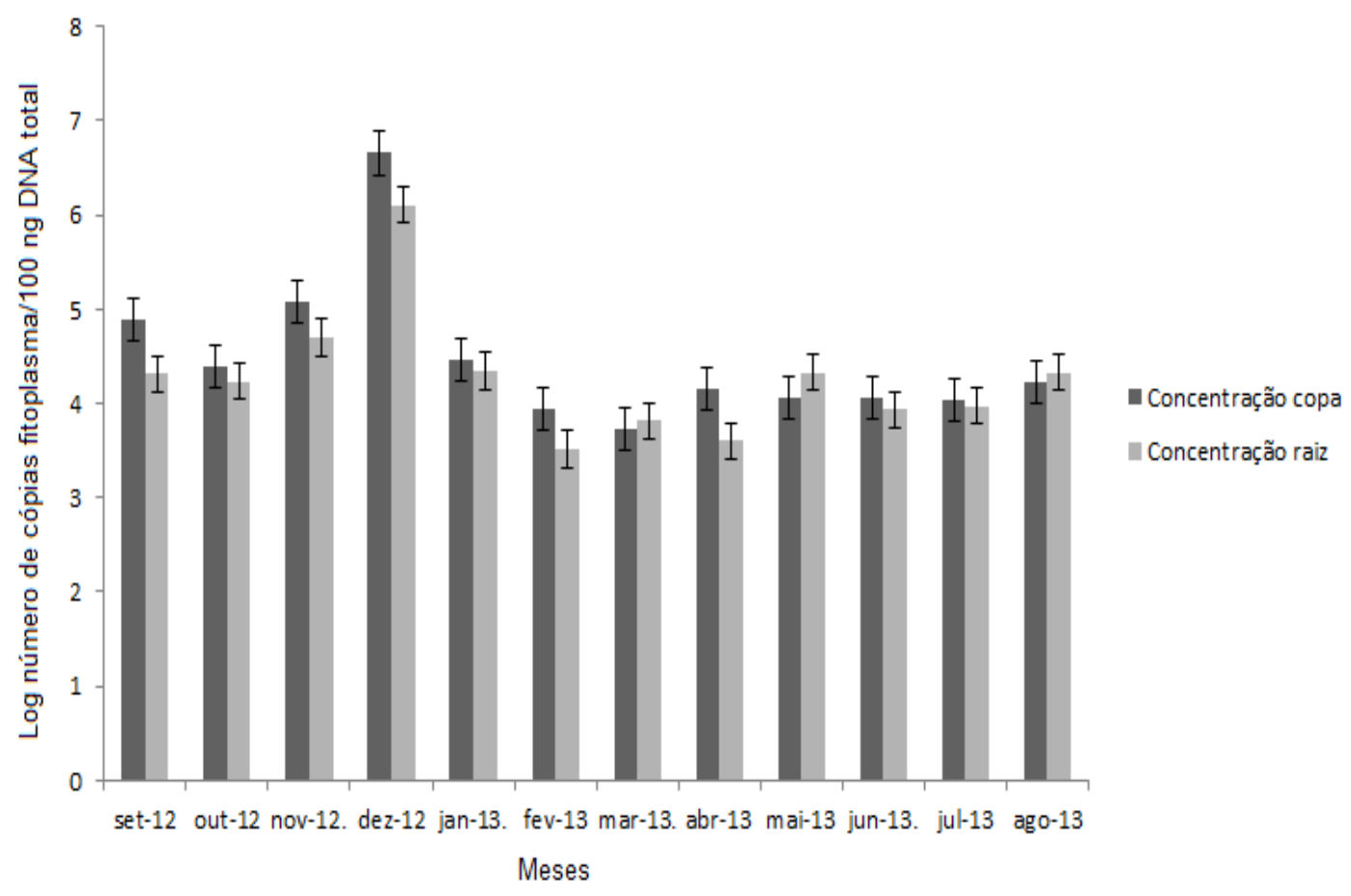

Figura 6 - Log do número de cópias de fitoplasma detectadas em 100 ng de DNA total de ameixeira (média total) via qPCR durante os 12 meses de avaliação, para copa e raiz. As barras representam o erro padrão da média

Ao contrário de vários trabalhos que estudaram o modelo de colonização de fitoplasmas em diversos hospedeiros, os resultados da presente pesquisa revelaram que o patógeno permaneceu na copa das árvores de ameixeira no estádio correspondente à dormência da planta. Este estádio ocorre nas épocas de temperaturas mais amenas do ano e, apesar da permanência do fitoplasma na parte aérea da planta durante a dormência da mesma, a sua concentração foi alterada em comparação com os valores encontrados nas épocas mais quentes do ano. Neste caso, as concentrações foram reduzidas da escala de $10^{6}$ para $10^{3}$ número de cópias de fitoplasma/100ng de DNA total, considerando-se as estimativas feitas nos meses mais quentes do ano e naqueles mais frios, respectivamente. Alguns trabalhos realizados em plantas lenhosas relataram a ocorrência do mesmo modelo de colonização verificado nesse trabalho. Assim, Jarausch et al., 1999 relatou que em ameixeira europeia, fitoplasmas foram detectados na parte aérea da planta mesmo durante o período de inverno. Em pereira e nectarineira os fitoplasmas também foram detectados nos períodos mais frios na parte aérea da planta (JAWHARI et al., 2014). Na região do mar Mediterrâneo, onde as temperaturas são mais elevadas e não há a ocorrência de um inverno rigoroso, 'Ca. Phytoplasma pyri' 
foi encontrado colonizando a parte aérea de pereira por um período de tempo mais longo (ERREA et al., 2002; GARCIA-CHAPA, 2003). Flôres, 2013 realizou o mesmo tipo de trabalho em pomares instalados no estado de São Paulo, no período de setembro de 2011 a agosto de 2012. Os resultados obtidos mostraram que os fitoplasmas foram encontrados na parte aérea da planta durante o período de dormência, porém com uma redução na concentração do patógeno da escala de $10^{9}$ para $10^{5}$ número de cópias de fitoplasma/100ng de DNA total. Os referidos resultados são plenamente concordantes com aqueles encontrados no presente trabalho.

Quando se analisou a interação entre parte da planta versus época de amostragem (meses do ano) foi possível observar que houve diferença significativa na concentração de fitoplasma no mês de dezembro, quando comparado com as outras épocas de amostragem (Tabela 4). Neste mês a concentração do patógeno foi maior tanto na parte aérea $\left(4,54 \times 10^{6}\right.$ número de cópias/100ng DNA total) quanto nas raízes $\left(1,28 \times 10^{6}\right.$ número de cópias/100ng DNA total). Os resultados revelaram também uma diferença significativa na concentração de fitoplasma entre copa e raiz, nos meses de setembro, novembro e dezembro. Em todas essas épocas de amostragem a concentração do patógeno foi maior na parte aérea da planta (Tabela $4)$.

Os resultados aqui apresentados evidenciaram que a concentração de fitoplasma na planta é maior em épocas mais quentes do ano, principalmente no mês de dezembro. De acordo com dados do INMET, o mês de dezembro de 2012 foi o que apresentou as temperaturas mais altas durante todo ano, com mínima de $20^{\circ} \mathrm{C}$ e máxima de $30^{\circ} \mathrm{C}$. A concentração do patógeno nesse mês foi maior na parte aérea da planta. Nessa época do ano a planta de ameixeira está na fase frutificação, sendo assim os fotoassimilados produzidos pela planta estão se concentrando na copa para a formação dos novos frutos. Como os fitoplasmas são habitantes de floema e a seiva elaborada também é transportada por esse vaso condutor, acreditase que o patógeno seja carregado para a parte aérea da planta através desse fluxo de seiva. Além disso, a seiva elaborada é rica em carboidratos e os fitoplasmas utilizam essa fonte de carbono como principal forma de produzir energia (OSHIMA et al., 2007). Como nesse período a concentração de carboidratos está maior na parte aérea da planta, devido à fase de frutificação, a multiplicação do patógeno e 
consequentemente sua concentração será maior, já que as condições estão favoráveis ao seu desenvolvimento.

Tabela 4- Influência da época de amostragem e parte da planta (copa ou raiz) na concentração do patógeno nos tecidos do hospedeiro. Concentração = número de cópias/100ng DNA total

\begin{tabular}{ccccccc}
\hline $\begin{array}{c}\text { Época de } \\
\text { amostragem }\end{array}$ & $\begin{array}{c}\text { Concentração } \\
\text { Copa }\end{array}$ & \multicolumn{3}{c}{$\begin{array}{c}\text { Concentração } \\
\text { Raiz }\end{array}$} \\
\hline Setembro & $7,62 \times 10^{4}$ & b & A & $2,05 \times 10^{4}$ & b & B \\
Outubro & $2,51 \times 10^{4}$ & C & A & $1,70 \times 10^{4}$ & b & A \\
Novembro & $1,21 \times 10^{5}$ & b & A & $4,98 \times 10^{4}$ & b & B \\
Dezembro & $4,54 \times 10^{6}$ & a & A & $1,28 \times 10^{6}$ & a & B \\
Janeiro & $2,89 \times 10^{4}$ & C & A & $2,19 \times 10^{4}$ & b & A \\
Fevereiro & $8,76 \times 10^{3}$ & C & A & $3,28 \times 10^{3}$ & C & A \\
Março & $5,30 \times 10^{3}$ & C & A & $6,54 \times 10^{3}$ & C & A \\
Abril & $1,40 \times 10^{4}$ & C & A & $4,0 \times 10^{3}$ & C & A \\
Maio & $1,13 \times 10^{4}$ & C & A & $2,11 \times 10^{4}$ & b & A \\
Junho & $1,17 \times 10^{4}$ & C & A & $8,52 \times 10^{3}$ & C & A \\
Julho & $1,09 \times 10^{4}$ & C & A & $9,42 \times 10^{3}$ & C & A \\
Agosto & $1,64 \times 10^{4}$ & C & A & $2,12 \times 10^{4}$ & b & A \\
\hline
\end{tabular}

As médias seguidas pela mesma letra (minúscula) na mesma coluna não diferem entre si de acordo com o teste de Scott Knot a 5\% de propabilidade. As médias seguidas pela mesma letra (maiúscula) em coluna diferente não diferem entre si de acordo com o teste de Scott Knot a $5 \%$ de propabilidade.

Flôres, 2013 relatou o mesmo modelo de colonização de fitoplasma apresentado nesse trabalho. Durante o ano de avaliação (setembro de 2011 a agosto de 2012), o patógeno foi encontrado em maior concentração nos meses mais quentes e sua concentração foi reduzida durante os meses de temperaturas mais amenas. Também foi relatada diferença significativa na concentração do fitoplasma entre copa e raiz nos meses de outubro e novembro, sendo que em novembro a concentração de fitoplasma foi maior na parte aérea da planta. Os resultados de Flôres, 2013 são congruentes com aqueles obtidos no presente trabalho, reforçando que o estádio de frutificação da árvore e a ocorrência de 
temperaturas mais elevadas neste período do ano são fatores favoráveis ao aumento da concentração do patógeno nos tecidos vegetais.

Tanto neste trabalho como naquele realizado por Flôres, 2013, o patógeno foi encontrado tanto na parte aérea como nas raízes das amostras coletadas durante todos os meses do ano. Com base nesta observação, para fins de diagnose da doença complementada pela detecção do patógeno, as amostras de tecidos podem ser retiradas tanto da copa como da raiz, principalmente nos meses mais quentes do ano. No entanto, as folhas são mais indicadas para o processo de diagnose por serem mais adequadas ao processo de extração de DNA, sobretudo na etapa de maceração do tecido vegetal. O presente trabalho e aquele de Flores, 2013 são concordantes em que setembro a dezembro são os melhores meses para a coleta de amostras visando à detecção do patógeno. Isto se deve a conjunção de dois fatores, ou seja, presença de folhas na planta e ocorrência de temperatura elevada. 


\section{CONCLUSÕES}

- O modelo de colonização das plantas de ameixeira infectadas por fitoplasma mostrou-se influenciado pela temperatura, com maior concentração do patógeno nos períodos mais quentes do ano e uma redução nas épocas mais frias;

- O patógeno permaneceu na parte aérea da planta mesmo no período de dormência do hospedeiro;

- A variedade Gulfblaze apresentou maior concentração de fitoplasma em relação à variedade Azteca;

- Os fitoplasmas foram encontrados em maior concentração na parte aérea da planta;

- As épocas mais quentes do ano, principalmente os meses de setembro a dezembro, mostraram-se como as melhores épocas para obtenção de amostras para fins de diagnose;

- O estádio de frutificação da planta e a ocorrência de temperaturas mais elevadas são fatores favoráveis ao aumento da concentração do patógeno nos tecidos vegetais;

- Amostras de copa e raiz apresentaram os mesmos resultados com relação á detecção do patógeno, ou seja, o patógeno foi detectado em ambas as partes da planta. Porém, recomenda-se as amostras foliares e por serem mais facilmente manipuladas nos procedimentos de extração de DNA total;

- A técnica de PCR quantitativo (Real time) é indicada para detecção do fitoplasma encontrado em plantas de ameixeira. Essa técnica demostrou eficiência, rapidez e segurança em seus resultados, sugerindo assim, seu uso em laboratórios responsáveis por inspeção quarentenária. 


\section{REFERÊNCIAS}

ALDAGHI, M., MASSART, S., ROUSSEL, S., \& JIJAKLI, M. H. Development of a new probe for specific and sensitive detection of 'Candidatus Phytoplasma mali'in inoculated apple trees. Annals of Applied Biology, Warwick, v.151, p. 251-258, 2007.

AMARAL MELLO, A. P. O. Identificação molecular de fitoplasmas associados ao enfezamento do repolho e análise epidemiológica da doença. 2007. 64 p. Tese (Doutorado em Fitopatologia) - Escola Superior e Agricultura "Luiz de Queiroz", Universidade de São Paulo, Piracicaba, 2007.

APPLIED BIOSYSTEMS. Apostila. Aplicações da PCR quantitativa em Tempo Real. São Paulo, 2009. p.51.

BARBOSA, W. Gulfblaze: nova opção de ameixa para o Estado de São Paulo. Disponível em: <http://www.infobibos.com/Artigos/Ameixa/Ameixa.htm>. Acesso em: 4 nov. 2015.

BARIC, S. Quantitative real-time PCR analysis of 'Candidatus Phytoplasma mali'without external standard curves. Erwerbs-Obstbau, Berlin, v.54, p.147-153, 2012.

BARIC, S.; BERGER,J.; CAINELLI, C.; KERSCHBAMER,C.; LETSCHKA, T.; DALLA-VIA,J. Seasonal colonization of apple trees by 'Candidatus Phytoplasma mali' revealed by a new quantitative TaqMan real-time PCR approach. European Journal of Plant Pathology, Dordrecht, v.129, p.455-467, 2011.

\section{BARROS, T.S.T. Caracterização Molecular de Mollicutes Fitopatogênicos no} Brasil. 2002. 105 p. Tese (Doutorado em Fitopatologia) - Universidade de Brasília, Brasília, 2002.

BEDENDO, I.P. Fitoplasma e espiroplasma. In: AMORIM, L.; REZENDE, J.A.M; BERGAMIN FILHO, A. Manual de fitopatologia: princípios e conceitos. 4. ed. São Paulo: Agronomica Ceres, 2011. p. 255-270.

BERGES, R., ROTT, M., SEEMULLER, E. Range of phytoplasma concentrations in various plant hosts as determined by competitive polymerase chain reaction.

Alemanha, Phytopathology, Saint Paul, v.90, p.1145-1152, 2000.

BERTACCINI, A.; DUDUK, B. Phytoplasma and phytoplasma diseases: a review of recente research. Phytopathologia Mediterranea, Bologna, v. 48, p.355-378, 2009.

BOSCO, D.; GALETTO, L.; LEONCINI, P.; SARACCO, P.; RACCAH, B.;

MARZACHI, C. Interrelationships between 'Candidatus Phytoplasma asteris' and its leafhopper vectors. Journal of Economic Entomology, Lanham, v.100, p.15041511, 2007. 
BRIOSO, P. S. T.; MONTANO, H. G. Fitoplasma do grupo $16 \mathrm{~S}$ rRNA I associado ao amarelecimento fatal de Elaeis guineensis. In: XXVI Congresso Paulista de Fitopatologia, 2003, Araras, SP. Summa Phytopathologica, Jaguariúna, v. 29. p. 81-81, 2003.

CASTRO, L. A. S.; CAMPOS, A. D. Ameixa: produção. Brasília, Embrapa Informação Tecnológica, 2003. 115p. (Série Frutas do Brasil, 43).

CASTRO, L.A.S., NAKASU, B.H.; FORTES, J.F.; CANTILLANO, R.F.F.; FREIRE, C.J. da S.; MEDEIROS, A.R.M. de; RASEIRA, A.; FINARDI, N.L.; CAMELATTO, D. A cultura da ameixeira. Brasília: EMBRAPA-SPI, 1994. 67p. (Coleção Plantar, 9).

CASTRO, L.A.S; NAKASU, B.H; PEREIRA, J.F.M. Ameixeira: Histórico e perspectiva de cultivo. Pelotas: Embrapa Clima Temperado, 2008.10p. (Circular Técnica, 70).

CIESLINSKA, M. Less common phytoplasmas infecting stone fruits trees. Journal of Plant Protection Research, Poznan, v.51, p.435-440, 2011.

DAVIS, R.E. Fitoplasmas: fitopatógenos procarióticos sem parede celular, habitantes de floema e transmitidos por artrópodes. Revisão Anual de Patologia de Plantas, Passo Fundo, v.3 p. 1-27, 1995.

DEL SERRONE, P.; BARBA, M. Importance of the vegetative stage for phytoplasma detection in yellow-diseased grapevines. Vitis, Siebeldingen, v. 5, n. 2, p. 101-102, 1996.

DOI, Y.; TERANAKA, M.; YORA, K.; ASUYAMA, H. Mycoplasma or PLT grouplike microrganisms found in the phloem elements of plants infected with mulberry dwarf, potato witches' broom, aster yellows or pawlonia witches' broom. Annals of Phytopathological Society Japan, Tokyo, v.33, p. 259-266, 1967.

DOYLE, J.J; DOYLE, J.L. Isolation of plant DNA from fresh tissue. Focus, Ithaca, v.12, p.13-15, 1990.

ECKSTEIN, B. Identificação molecular de um fitoplasma associado á malformação das folhas das ornamentais Celosia argêntea L. e Celosia spicata L. 2008. 50p. Dissertação (Mestrado em Fitopatologia) - Escola Superior de Agricultura "Luiz de Queiroz", Universidade de São Paulo, Piracicaba, 2008.

EIDAM, T.; PAVANELLO, A.P. Ameixeira no Brasil. Revista Brasileira de Fruticultura, Cruz das Almas, v.34 p. 001-319, 2012.

ERREA, P.; AGUELO, V.; HORMAZA, J.I. Seasonal variations in detection and transmission of pear decline phytoplasma. Journal of Phytopathology, Berlin, v.150, p.439-443, 2002.

FAOSTAT. Production-crops. Disponivel em: <htpp://faostat.fao.org >. Acesso em: 30 jun. 2015. 
FERNÁNDEZ, F. D.; GUZMÁN, F. A.; CURZEL, V.; BEJARANO, N., \& CONCI, L. R. Detection and molecular characterization of a phytoplasma affecting Prunus persica L. in Jujuy, Argentina. European Journal of Plant Pathology, Dordrecht, v.135, p.627-63, 2013.

FIALOVÁ, R.; NAVRÁTIL, M.; VÁLOVÁ, P.; LAUTERER, P.; KOCOUREK, F.; POCAROVÁ-VORÁCKOVÁ, Z. Epidemiology of European stone fruit yellows pytoplasma in the Czech Republic. Acta Horticulturae, The Hague, v. 657, p.483487, 2004.

FLÔRES, D. Amarelo da ameixeira: caracterização molecular do fitoplasma e modelo de colonização do hospedeiro. 2013. 67p. Tese (Doutorado em Fitopatologia) - Escola Superior de Agricultura "Luiz de Queiroz", Universidade de São Paulo, Piracicaba, 2013.

FOISSAC, X.; WILSON, M.R. Current and possible future distributions of phytoplasma diseases and their vectors. In: WEINTRAUB, P.G.; JONES, P. Phytoplasmas: genomes, plant hosts and vectors. Wallingford: CAB International, 2010. chap.17, p.309-324,

GALETTO,L.; MARZACHÍ, C. Real-time PCR Diagnosis and Quantification of Phytoplasmas. In: WEINTRAUB, P.G.; JONES, P. Phytoplasmas: genomes, plant hosts and vectors. Wallingford: CAB International, , 2010. chap. 1, p.1-18,

GARCIA-CHAPA, M.; MEDINA, V.; VIRUEL, M.A.; LAVINA, A.; BATLLE, A. Seasonal detection of pear decline phytoplasma by nested PCR in different pear cultivars. Plant Pathology, London, v.52, p.513-520, 2003.

HOGENHOUT, S.A.; MUSIC, M.S. Phytoplasma genomics, from sequencing to comparative and functional genomics - What have we learnt? In: WEINTRAUB, P.G; JONES, P. Phytoplasmas: Genomes, Plants Hosts and Vectors. Wallingford: CAB International, chap 2, p 19-36, 2010.

HREN, M., BOBEN, J., ROTTER, A., KRALIJ, P., GRUDEN, K., \& RAVNIKAR, M. Real-time PCR detection systems for Flavescence dorée and Bois noir phytoplasmas in grapevine: comparison with conventional PCR detection and application in diagnostics. Plant pathology, London, v.56, p.785-796, 2007.

HUANG, D., WALLA, J. A., \& DAI, W. Quantitative phenotyping of X-disease resistance in chokecherry using real-time PCR. Journal of Microbiological Methods, Amsterdam, v.98, p.1-7, 2014.

INMET. Dados climáticos. Disponível em <htpp://inmet.gov.br>. Acesso em: 04 nov. 2015.

JARAUSCH, B.; JARAUSH, W. Psyllid vectors and their control. In: WEINTRAUB, P.G; JONES, P. Phytoplasmas: Genomes, Plants Hosts and Vectors. Wallingford: CAB International, 2010. chap 2, p 19-36. 
JARAUSCH, W.; LANSAC, M.; DOSBA, F. Seasonal colonization pattern of European stone fruit yellows phytoplasma in different Prunus species detected by specific PCR. Journal of Phytopathology, Berlin, v. 147, p.47-54, 1999.

JAWHARI, M., ABRAHAMIAN, P., SATER, A. A., SOBH, H., TAWIDIAN, P., \& ABOU-JAWDAH, Y. Specific PCR and real-time PCR assays for detection and quantitation of 'Candidatus Phytoplasma phoenicium'. Molecular and Cellular Probes, London, v.29, p.63-70, 2015.

KIST,B.B.; VENCATO,A.C.; SANTOS,C.; CARVALHO,C.; REETZ,E.R.; POLL,H.; BELING, B.R.; Anuário brasileiro da fruticultura 2012. Santa Cruz do Sul: Editora Gazeta Santa Cruz, 2012.128p.

LEE, I.M.; DAVIS, R.E.; GUNDERSEN-RINDAL, D.E. Phytoplasma: Phytopathogenic Mollicutes. Annual Review of Microbiology, Palo Alto, v.54, p.221-255, 2000.

LEE, I.M.; GUNDERSEN-RINDAL, D.E.; DAVIS, R.E; BARTOSZYK, I.M. Revised classification scheme of phytoplasmas based analyses of 16S rDNA and ribosomal protein gene sequences. International Journal of Systematic and Evolutionary Microbiology, Reading, v.48, p.1153-1169, 1998.

LI, Z., SONG, S., ZHANG, L., GAO, L., \& WU, Y. Identification of the phytoplasma associated with peach yellows disease in northwest China. Canadian Journal of Plant Pathology, Ontario, v.36, p.151-160, 2014.

LI, Z. N., ZHANG, L., Ye, T. A. O., Ming, C. H. I., XIANG, Y., \& WU, Y. F. A New Disease of Cherry Plum Tree with Yellow Leaf Symptoms Associated with a Novel Phytoplasma in the Aster Yellows Group. Journal of Integrative Agriculture, China, v.13, p.1707-1718, 2014.

LOI, N. ERMACORA, P., CARRARO, L., OSLER, R., CHEN, T. A. Production of monoclonal antibodies against apple proliferation phytoplasma and their use in serological detection. European Journal of Plant Pathology, Dordrecht, v. 108, p. 81-86, 2002.

MADAIL, J.C.M. Aspectos socioeconômicos. Brasília, Embrapa Informação Tecnológica, 2003. 15p. (Série Frutas do Brasil, 43).

MANIMEKALAI, R., NAIR, S., SOUMYA, V. P., ROSHNA, O. M., \& THOMAS, G. V. Real-time PCR technique-based detection of coconut root (wilt) phytoplasma. Current Science, Bangalore, v.101, p.1209-1214, 2011.

MARCONE, C. Movement of phytoplasma and the development of disease in the plant. In: WEINTRAUB, P.G; JONES, P. Phytoplasma: genomes, plant hosts and vectors. Wallingford: CAB International, 2010. chap. 7 p.114-131

MARTINI, M.; LOI, N.; ERMACORA, P.; CARRARO, L., PASTORE, M. A real-time PCR method for detection and quantification of 'Candidatus Phytoplasma prunorum' in its natural hosts. Bulletin of Insectology, Bologna, v.60, p.251-252, 2007. 
MONTANO, H.G.; CUNHA JUNIOR, J.O.; PIMENTEL, J.P. Phytoplasmas in Brazil: na update. Bulletim of Insectology, Bologna, v.64, p.251-252, 2011.

MONTEIRO, L.B.; MIO, L.L.M.; SERRAT, B.M.; MOTTA, A.C.V.; CUQUEL, F.L. Fruteiras de caroço uma visão ecológica. Curitiba: UPPR, 2004. 390p.

NATIONAL CENTER FOR BIOTECHNOLOGY INFORMATION - NCBI. Disponível em: < http://www.ncbi.nlm.nih.gov/taxonomy>. Aceso em: 14 nov. 2015.

NOVAIS, M.C.; ALVES, P.M. PCR em tempo real: Uma inovação da reação em cadeia da polimerase (PCR). Biotecnologia Ciência e Desenvolvimento, Rio Grande do Sul, v.33, p.10-13, 2004.

OLIVEIRA D. E., FERNANDES T. F., PINTO A D. J. F. N., DOENÇAS DO MILHO: Identificação e controle. Sete Lagoas, Embrapa Milho e Sorgo, 2005, 84p. (Circular técnica, 26).

OSHIMA, K., KAKIZAWA, S., ARASHIDA, R., ISHII, Y., HOSHI, A., HAYASHI, Y. Presence of two glycolytic gene cluster in a severe pathogenic line of 'Canditatus Phytoplasma asteris'. Molecular Plant Pathology, London, v.8, p.481-489, 2007.

PEDRAZZOLI, F., CICCOTTI, A., BIANCHEDI, P., SALVADORI, A., ZORER, R. Seasonal colonization behavior of 'Canditatus Phytoplasma mali' in apple trees in Tretino. Acta Horticulturae, The Hague, v. 781, p. 483-489, 2008.

PEREIRA, T. B. C. Identificação molecular de um fitoplasma do grupo 16Srl-B em plantas de soja. 2011. 66p. Dissertação (Mestrado em fitopatologia) - Escola Superior de Agricultura "Luiz de Queiroz", Universidade de São Paulo, Piracicaba, 2011.

SABATO, O E.; LANDAU, C. E.; Influência da temperatura nos sintomas causados pelo enfezamento pálido do milho. Sete Lagoas, Embrapa Milho e Sorgo, 2010, 6p. (Circular Técnica, 151).

SCHNEIDER, B.; AHRENS, U.; KIRKPATRICK, B.C.; SEEMULLER,E. Classification of plant-pathogenic mycoplasma like organisms using restriction-site analysis of PCR-amplified 16SrDNA. Journal of General Microbiology, London, v.139, p.519527, 1993.

SILVA, F.A.S. ASSISTAT: Versão 7.7 beta. DEAG-CTRN-UFCG - Atualizado em 01 de abril de 2014. Acessado em: 20 maio 2015.

TEIXEIRA, D.C.; WULFF, N. A.; MARTINS, E.C.; KITAJIMA E. W.; BASSANEZI, R.; AYRES, A. J.; EVEILLARD, S.; SAILLARD, C.; BOVÉ, J.M. A phytoplasma related to 'Candidatus Phytoplasma asteri' detected in citrus showing huanglonbing (yellow shoot disease) symptoms in Guangdong, P. R. China. Phytopathology, Saint Paul, v.99, p.236-242, 2009. 
TORRES, E., BERTOLINI, E., CAMBRA, M., MONTÓN, C., \& MARTÍN, M. P. Realtime PCR for simultaneous and quantitative detection of quarantine phytoplasmas from apple proliferation (16SrX) group. Molecular and Cellular Probes, London, v.19, p. 334-340, 2005.

VERDIN, E.; SALAR, P.; DANET, J.L.; CHOUEIRI, E.; JREIIJRI, F.; EL ZAMAR, S.; GELIB, B.; BOVÉ, J. M.; GARNIER, M. 'Canditatus Phytoplasma phoenicium' sp. nov., a novel phytoplasma associated with an emerging lethal disease of almond trees in Lebanon and Iran. International Journal of Systematic and Evolutionary Microbiology, Reading, v.53, n.3, p.833-838, 2003.

WANG, L. P.; HONG, N.; XU, W. X.; WANG, Y. F.; CHOFONG, G. N.; MARTINI, M.; \& WANG, G. P. Identification and molecular characterization of $16 \mathrm{SrV}$ group phytoplasmas with flowering cherry in China. European Journal of Forest Pathology, Hamburg, v.44, p.166-168, 2014.

WEI, W.; DAVIS, R.E.; LEE, I-M.; ZHAO, Y. Computer simulated RFLP analysis of $16 S$ rRNA genes: identification of ten new phytoplasma groups. International Journal of Systematic and Evolutionary Microbiology, Reading, v.57, p.18551867, 2007.

ZHANG, L., LI, Z. N., ZHANG, H. W., TAO, Y., \& WU, Y. F. Detection and Identification of Aster Yellows Group Phytoplasma (16Srl-C) Associated with Peach Red Leaf Disease. Journal of Phytopathology, Berlin, v.161, p. 359-362, 2013.

ZHAO, Y.; WEI, W.; LEE, I-M.; SHAO, J.; SUO, X.; DAVIS, R.E. Construction of an interactive online phytoplasma classification tool, iPhyClassifier, and its application in analysis of the peach X-disease phytoplasma group (16SrIII). International Journal of Systematic and Evolutionary Microbiology, Reading, v.59, p.2582-2593, 2009. 